\title{
ANTARCTIC FISH METABOLIC RESPONSES AS POTENTIAL BIOMARKERS OF ENVIRONMENTAL IMPACT
}

\author{
Edson Rodrigues ${ }^{1, *}$, Cecília N. K. Suda ${ }^{1}$,Edson Rodrigues Júnior ${ }^{2}$, Mariana Feijó de Oliveiral, Cleoni \\ dos Santos Carvalho ${ }^{3}$, Gannabathula Sree Vani ${ }^{1}$ \\ ${ }^{1}$ Universidade de Taubaté (UNITAU), Instituto Básico de Biociências, Departamento de Biologia, Campus do Bom Conselho, Av. Tiradentes, 500 - \\ Centro, Taubaté, SP, Brazil. CEP: 12.030-180. \\ ${ }^{2}$ Universidade Federal do Paraná (UFPR), Programa de Pós-graduação em Biologia Molecular e Celular, Centro Politécnico s/No, Jd das Américas, \\ Curitiba, PR, Brazil. CEP: 81.990-970. \\ ${ }^{3}$ Universidade Federal de São Carlos (UFSCar), Campus Sorocaba, Departamento de Biologia, Rod. João Leme dos Santos Km 110 - SP-264, Itinga, \\ Sorocaba, SP, Brazil. CEP: 18.052-780. \\ E-mails: rodedson@gmail.com, edsonrodj@gmail.com, cecilia.suda@unitau.com.br, srvani@hotmail.com,carvcleo@yahoo.com.br
}

\begin{abstract}
Most of the biochemical and physiological studies of Antarctic fish were directed to understand the molecular adaptation of these ectotherms to low temperatures and limits of their metabolic plasticity associated with thermal stress. The principal objective of this review is to discuss the energy metabolism, of L-arginine, antioxidant defense and the xenobiotics of Antarctic fishes as possible markers of environmental change. With the establishment of the circumpolar current and the physical isolation of the region, Antarctic fishes evolved under stable low temperatures. The elevated endemism, low diversity, and the probable stenothermality motivated a number of studies on Antarctic fishes. The presence of enzymes with physical and chemical properties adapted to low temperatures was evident in various studies and fortified the cold adaptation concept of these organisms. By ratifying the Antarctica Environmental Protection Treaty (Madrid protocol), the member countries committed themselves to monitoring the environment of the region. Though, it is one of the most pristine regions of the planet, increasing human activity in Antarctica has given rise to concerns about pollution from combustion oils, heavy metals and sewage. As the energy sustainability of the tissues requires that the velocity of the ATP generator systems should be in step with the energy demand, changes in the environment would lead to elevation in the energy demand of the organisms, which in turn demanded an adjustment of the ATP synthesis velocity. In these cases the enzymatic upregulation and downregulation have been used as biomarkers of the energy metabolism. Traditionally, the antioxidant defense enzymes and the xenobiotic metabolism of fishes have been used as biomarkers to access the natural or anthropic environmental change. However, these studies must correlate the levels of enzymes with the principal risk factors in the environmental pollution. L-arginine metabolism enzymes have been used as biomarkers of the physiological response in mammals, but there are few studies on Antarctic fishes. The central role of the amino acid L-arginine in the synthesis of nitric oxide, polyamines and as a signal in various physiological processes has drawn the attention of scientists. The tissue distribution and the isoforms distribution, along with its control via upregulation and downregulation of the arginase enzymes, nitric oxide synthase and ornithine decarboxylase in Antarctic fishes are potential biomarkers for environmental change.
\end{abstract}

Keywords: Antarctica; fish; biomarkers; metabolism; environment.

\section{RESUMO}

RESPOSTAS METABÓLICAS DE PEIXES ANTÁRTICOS COMO MARCADORES DE IMPACTO AMBIENTAL. Boa parte dos estudos bioquímicos e fisiológicos com peixes Antárticos foram conduzidos objetivando entender a adaptação molecular desses organismos ectotérmicos às baixas temperaturas, bem como os limites da sua plasticidade metabólica associada com o estresse termal. O principal objetivo desta revisão 
é discutir os metabolismos energético, da L-arginina, de xenobióticos e da defesa antioxidante dos peixes antárticos. Com o estabelecimento da Corrente Circumpolar Antártica e o isolamento geográfico da região, os peixes antárticos evoluíram sob temperaturas baixas e estáveis. O número elevado de espécies endêmicas, a baixa diversidade e a provável estenotermia motivaram diversos estudos com peixes antárticos. A presença de enzimas com propriedades fisico-químicas adaptadas a baixa temperatura ficou evidente em vários estudos e reforçou o conceito de adaptação ao frio. Ao ratificar o Protocolo de Proteção Ambiental para o Tratado da Antártica (protocolo de Madri), os países membros se comprometeram com o monitoramento ambiental da região. Embora seja considerada a região mais preservada do planeta, a presença humana crescente na Antártica tem motivado preocupações em relação à poluição por óleo combustível, metais pesados e esgoto. A sustentabilidade energética dos tecidos requer que a velocidade de síntese de ATP pelos seus sistemas geradores esteja em consonância com a demanda energética. Mudanças ambientais podem elevar a demanda energética dos organismos e, por sua vez, demandar ajustes na velocidade de síntese de ATP. Nesse caso, os aumentos ou reduções dos níveis enzimáticos tem sido utilizados como biomarcadores do metabolismo energético. Tradicionalmente, enzimas da defesa antioxidante e do metabolismo de xenobióticos de peixes tem sido utilizadas como biomarcadoras para indicar alterações ambientais naturais ou antrópicas. Estes estudos devem correlacionar os níveis de atividade enzimática com a presença do principal fator de risco da poluição ambiental. As enzimas do metabolismo da L-arginina tem sido utilizadas como biomarcadoras de respostas fisiológicas em mamíferos, mas há poucos estudos sobre peixes antárticos. A função do aminoácido L-arginina na síntese de óxido nítrico, poliaminas e como sinalizador em vários processos fisiológicos tem chamado a atenção de pesquisadores. A distribuição tecidual e a distribuição de isoformas, bem como o controle via upregulation e downregulation das enzimas arginase, óxido nítrico sintase e ornitina descarboxilase de peixes antárticos representam potenciais biomarcadores de alterações ambientais.

Palavras-chave: Antártica; peixe; biomarcador; metabolismo; ambiente.

\section{RESUMEN}

\section{RESPUESTAS METABÓLICAS DE PECES ANTÁRTICOS COMO POTENCIALES} MARCADORES DE IMPACTO AMBIENTAL. La mayoría de los estudios bioquímicos y fisiológicos de los peces antárticos fueron realizados para entender las adaptaciones moleculares de estos organismos ectotérmicos a las bajas temperaturas, así como también los límites de su plasticidad metabólica asociado al estrés térmico. El principal objetivo de esta revisión es discutir como posibles marcadores del cambio ambiental a los metabolismos energéticos de la L-arginina, de los xenobioticos y de las defensas antioxidantes de los peces antárticos. Con el establecimiento de la Corriente Circumpolar Antártica y el aislamiento geográfico de la región, los peces antárticos evolucionaron en condiciones estables de baja temperatura. El elevado endemismo, la baja diversidad y la probable estenotermia motivaron numerosos estudios en peces antárticos. La presencia de enzimas con propiedades físico-químicas adaptadas a las bajas temperaturas fue evidente en varios estudios y reforzó el concepto de adaptación al frío de estos organismos. En la ratificación del Protocolo al Tratado Antártico sobre Protección del Medio Ambiente (Protocolo de Madrid), los países miembros se comprometieron al monitoreo ambiental de la región. Si bien es una de las regiones más prístinas del planeta, el aumento de la actividad humana en Antártida ha generado preocupación en relación con la polución generada por los aceites de combustión, los metales pesados y las aguas de desecho. La sustentabilidad energética de los tejidos requiere que la velocidad de síntesis de ATP, a partir de sus sistemas generadores, deba estar sincronizada con la demanda de energía. Cambios en el ambiente conllevarán un aumento en las demandas energéticas de los organismos, que a su turno demandarán un ajuste de la velocidad de síntesis del ATP. En estos casos, los aumentos o disminuciones de los niveles enzimáticos han sido utilizados como biomarcadores del metabolismo energético. Tradicionalmente, las enzimas de defensa antioxidante y del metabolismo de xenobioticos de peces han sido utilizadas como biomarcadores para indicar alteraciones ambientales naturales o de origen antrópico. Estos estudios deben correlacionar los niveles de actividad enzimática con los principales factores de riesgo de la polución ambiental. Las enzimas del metabolismo de la L-arginina han sido utilizadas como biomarcadores 
de las respuestas fisiológicas en mamíferos, pero existen pocos trabajos en peces antárticos. El rol central del aminoácido L-arginina en la síntesis de oxido nítrico, poliaminas y como señal en varios procesos fisiológicos ha llamado la atención de los investigadores. La distribución de tejidos e isoformas, así como también su control, vía la regulación de las enzimas arginasas, síntesis de oxido nítrico y la ornitina descarboxilasa en peces antárticos son potenciales biomarcadores de cambios ambientales.

Palabras clave: Antártida; peces; biomarcadores; metabolismo; ambiente.

\section{INTRODUCTION}

The present Antarctic fish fauna evolved under the selective pressure of low temperatures and seasonality imposed by the long austral winters. After the breakup of the super continent, Gondwana and the movement of Antarctica towards the South Pole $(\approx$ 40 million years ago), the temperatures of the austral ocean decreased gradually from $15^{\circ} \mathrm{C}$ to the near freezing point. This cooling was accelerated in the last 2 million years, when the temperature declined $\left(0.25^{\circ} \mathrm{C} / 100,000\right.$ years $)$ from about $5^{\circ} \mathrm{C}$ to the present values, but still considered enough for the adaptive evolution of Antarctica fishes (Eastman 1993).

The south Antarctic Polar Frontier compiled data of ichthyofauna show the existence of 322 species distributed in 50 families and dominated by benthic fishes $(70 \%)$ of the Notothenioidei family (Figure 1) (Eastman 2005). Even though the marine fishes are represented by approximately 16,764 species, the ichthyofauna of Antarctica is only $1.9 \%$ of these species (Eschmeyer et al. 2010). Every year, about 100-150 new species of marine fish are described in a total of 5,000 not reported (Eschmeyer et al. 2010). In the Antarctic marine environment, the unknown ichthyofauna was estimated to be about 64 species by Eastman (2005). The most important molecular change in the adaptive evolution of Antarctic fish was the antifreeze glycoproteins (AFGP) in biological fluids about 5 to 14 million years ago. These class of proteins probably derived from mutation in the trypsinogen gene, is responsible for the fluidity of the biological fluids in notothenioids in subzero temperatures (Chen et al. 1997).

Studies of the physicochemical properties of enzymatic proteins and non-enzymatic proteins of Antarctic fishes and their distinction from their homologues encountered in temperate water fishes are corroborated to understand the physiological systems of fishes in subzero temperatures (Somero 2004). The elevated values of enthalpy and the polymerization entropy of isolated tubulin in Antarctic fishes Notothenia coriiceps, Notothenia gibberifrons and the icefish Chaenocephalus aceratus, compared to those of temperate water fishes and homeothermic animals, are compatibles with the polymerization of tubulin at $0^{\circ} \mathrm{C}$ (Detrich III 1991). Considering the central role played by ATP generation process and the energetic demand of the physiological systems, biochemists and physiologists have concentrated their studies on the energy metabolism. Enzymes with low values of $\mathrm{Km}$ and $\mathrm{K}_{0,5}$, along with the elevated values of Kcat, have sustained the evolutionary metabolic compensation of the Antarctic fishes at low temperatures (Clarke 2003, Somero 2004). The enzyme phosphofructokinase (PFK) in the Antarctic fish Trematomus bernacchii, considered as the principal regulator enzyme in the glycolytic pathway, has $\mathrm{K}_{0,5}$ value for the substrate fructose-6-phosphate 20 fold less at $5^{\circ} \mathrm{C}$ than at $20^{\circ} \mathrm{C}$ (Rodrigues et al. 1994).

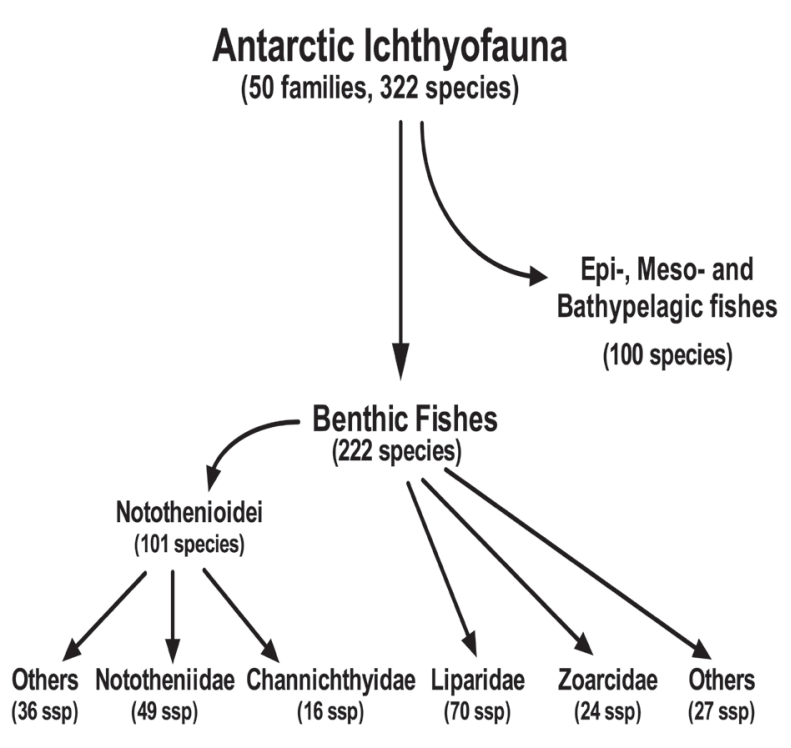

Figure 1. Diversity of the Antarctic fish fauna in the Southern Ocean. Notothenioidei, Liparidae and Zoarcidae taxa represent the largest number of benthic Antarctic fish species (60.6\%). Data compiled by Eastman (2005) 
Even though the Antarctic is one of the planets well preserved environment, scientists are concerned about increasing human activity in the region, particularly the localized pollution near scientific stations and near the anchorage of research and tourist ships. The sinking of Paradise Bay in 1989, near the Anvers Island in the Antarctic Peninsula spilled 600,000L of diesel oil and contaminated Antarctic fishes and invertebrate in an area of $100 \mathrm{~km}^{2}$ (Kennicutt II 1995, Janiot et al. 2003).

Discharge of sewage, burning of fossil fuels in the scientific stations, along with the leakage of small quantities of combustion oil when transferring it from ships to coastal stations are the principal sources Antarctic coastal regions pollution along with heavy metal and petroleum derivatives hydrocarbon (Duquesne \& Riddle 2002, Ahn et al. 2003).

Following the ratification of the Protocol on Environmental to the Antarctic Treaty (Madrid Protocol) in 1991, the members of the treaty have committed themselves to environmental monitoring and have made efforts to reduce the anthropic impact of their scientific activities in the region. The Specially Managed Antarctic Area (ASMA) in the Admiralty Bay $\left(362 \mathrm{~km}^{2}\right)$, located on the King George island (62 $02^{\prime}$ 'S and $\left.58^{\circ} 21^{\prime} \mathrm{W}\right)$, South Shetland Archipelago, has scientific stations from 5 nations (Brazil, Ecuador, Peru, Poland and USA) and is of Site of Special Scientific Interest (SSSI No 8) (Braun et al. 2001, Arigony-Neto et al. 2004). The human impact in the ASMA in Admiralty Bay and the environmental risks are higher during austral summer, as there is much movement of scientific and tourists ships, as well as the corresponding increase in the personnel and logistics, particularly those involving transfer of combustible from ships to scientific stations.

The monitoring of Admiralty Bay ASMA integrates goals of the National Institute of Antarctic Science, Technology and Environmental Research (INCT-APA) of the Brazilian Antarctic Program. Using a long time series of the physical, chemical and biological processes, INCT-APA is interested in understanding the natural and anthropic impacts in the region. The incorporation of biological information in the abiotic data amplifies the monitoring possibilities, predicting its effects on the biota and evaluating the environmental risk in case of contamination. All the biological responses arising from the changes in the physical and chemical environment have their origin at the molecular level, and reflected in the upper levels of the hierarchy such as biochemical, physiological, cellular and tissues (van der Oost et al. 2003).

The term biomarker is used to express measurable changes in the biological tissues and fluids at the molecular, biochemical, cellular and physiological levels. The changes arise at the sub individual level and are induced by the changes in the physical and chemical environments (van der Oost et al. 2003, Lam 2009). The advantages of using biochemical biomarkers in environmental monitoring as compared to the biological response at higher levels (populations, communities and ecosystems) is principally on the low cost of analysis, specificity and early changes to the biological answers (Lam 2009).

The use of fishes as bioindicators in environmental monitoring programs, rests on the fact that the species are easy to identify, are distributed in distinct trophic levels and have long life. Different from the sessile organisms, fishes express the stress factors within an area and offer ample information about the environment (Whitfield \& Elliott 2002, Shahidul Islam \& Tanaka 2004).

Biochemical biomarkers of fishes have been used to evaluate the pollutants impact on the environment and in the recovery of contaminated environments (Regoli et al. 2002, Linde-Arias et al. 2008). The selection of the sentinel organisms and biomarkers should be used with a lot of criteria, based on the scientific studies of the desired specificity and sensitivity to the detection of the toxic stress arising from changes in the environment.

The increasing anthropic activity in the region has given rise to concerns about the pollution of environment around the scientific stations and places where ships anchor. This article summarizes the enzymatic information on the L-arginine, xenobiotic, antioxidant defense and energy metabolism in Antarctic fish and their potential to study the environmental impacts.

\section{ENERGETIC METABOLISM}

Physiologists and biochemists have studied the energy metabolism of Antarctic organisms as the ATP generation process plays a central role in the functioning of other physiological systems (Clarke 2003). In 
vertebrates, three main metabolic pathways are used to maintain the tissue ATP level: a) generation of ATP from creatine phosphate; b) anaerobic catabolism of substrate (fermentation); and c) aerobic catabolism of the substrate (respiration) (Hochachka \& Somero 2002a). To sustain the tissues energy requirements, the velocity of the ATP generation systems must be in synchronism with the energy demand. The metabolic rate in Antarctic fishes depends partly on the expression of the enzymatic proteins with thermal kinetic properties that retain the catalytic efficiency at subzero temperatures. The presence of enzymes with more flexible structures, with elevated Kcat values and low $\mathrm{Km}$ have been interpreted as the homologous of those found in fishes in temperate waters, and have the adaptive advantages at low temperatures (Somero 2004). The quantity of the expressed proteins in the tissues is also an important modulator of the energy metabolism and is related to the metabolic rate in subzero temperatures (Hochachka \& Somero 2002a). This strategy permits the increase in the concentration of key energy metabolic enzymes (upregulation), compensating the negative effect of low temperature on the velocity of enzymatic reactions. Haschemeyer (1983) investigating the protein synthesis in the tissues of the Antarctic fish Notothenia coriiceps, Notothenia gibberifrons and Chaenocephalus aceratus, found that the velocity of the process is tissue specific and is expressively less in the icefish compared to the nototheniids. The protein synthesis was related to the alimentary state as well as the adaptation mechanisms to low temperatures.

Working with the isolated hepatocytes of the high Antarctic notothenioids (Trematomus eulepidotus, Trematomus pennellii, Trematomus lepidorhinus, Trematomus bernacchii and Artedidraco orianae) and the zoarcid Pachycara brachycephalum, as well as with the sub-Antarctic Lepidonotothen larseni, Mark et al. (2005) found that the energy allocated to the RNA synthesis, protein synthesis, Na,K-ATPase activity and mitochondrial ATP synthases, calculated from the inhibition effect of the oxygen consumption, is little influenced by the temperature in the range of $0^{\circ} \mathrm{C}$ to $15^{\circ} \mathrm{C}$. Assuming that this allocation of energy in the cell is maintained in the thermal range, the authors believed that the thermal limits could be related to the availability of $\mathrm{O}_{2}$ and also the energetic limitations at the higher organismal levels. The Antarctic fishes are a species with major stenothermality arising from the geographic isolation of the region and its subsequent chronic cooling (Coppes Petricorena \& Somero 2007). A knowledge of the thermal metabolic plasticity limits and the degree of stenothermality of Antarctic fishes are important for understanding the impact of raising temperatures on marine ecosystems (Drinkwater et al. 2010, Pörtner 2002). Temperature is considered as the principal stress agent that directly effects the velocity of chemical reactions, the fluidity of biological membranes, and indirectly all the physiological systems (Hochachka \& Somero 2002c). Thermal alterations in the aquatic environments affect the solubility of the dissolved oxygen ( $\mathrm{Wu} 2002)$ and hence the respiratory system in fishes. In Antarctic fishes Pagothenia borchgrevinki and Trematomus bernacchii, an increase in temperature (between 0 e $6^{\circ} \mathrm{C}$ ) is reflected in an increase in the velocity of oxygen consumption $\left(\mathrm{MO}_{2}\right)$ and a reduction in the osmolality and plasma glucose (Lowe \& Davison 2005). On the other hand, the post-exercise $\mathrm{MO}_{2}$ in $P$. borchgrevinki declined when the acclimatization temperature was raised from $3^{\circ} \mathrm{C}$ to $6^{\circ} \mathrm{C}$, indicating that the availability of oxygen limits the aerobic behavior at elevated temperatures (Lowe \& Davison 2006, Morrison et al. 2006). As the aerobic energy metabolism is the principal segment responsible for the ATP generation in mitochondria rich tissues and is limited by its utilization in the electron transfer chain (Hochachka \& Somero 2002b), the relation between oxygen availability and thermal changes could prevent important physiological activities in Antarctic fishes, such as locomotion.

The $\mathrm{MO}_{2}$ converted into energy units has been used to calculate the energy budget and the allocation of energy in the cell. The energy budget allocated for routine metabolic activities in the Antarctic fish Pachycara brachycephalum, does not have any significant alterations when acclimatization to temperatures between $0^{\circ} \mathrm{C}$ and $6^{\circ} \mathrm{C}$. However, changes in the metabolic parameters suggest that the total energy demand could be exceeding the total energy obtained from the feeding (Brodte et al. 2006a). An increase in the mitochondrial respiration in Antarctic fishes arising from an increasing temperature, could be exceeding the ATP demand or the availability of oxygen and, consequently accelerate the formation of reactive oxygen species in the respiratory chain. 
In this case, the increase in concentration of the uncoupling proteins (UCP) in the mitochondria of the Antarctic fish P. brachycephalum, aclimatized to $5^{\circ} \mathrm{C}$, has been considered as an important factor in the protection, accelerating the elimination of protons across the mitochondrial internal membranes and minimizing the formation of reactive oxygen species (Mark et al. 2006).

The ability to use oxygen as the final oxidant in the metabolic processes has been associated with the tissue level of enzymes of the energy metabolism. Working with fishes from different habitats, Torres \& Somero (1988a, 1988b) found a narrow relation between the velocity of oxygen consumption and the levels of the enzyme citrate synthase (CS) and lactato dehydrogenase (LDH). The enzymatic activities and the $\mathrm{MO}_{2}$ of fishes was conducted at $10^{\circ} \mathrm{C}$, using a $\mathrm{Q}_{10}$ of 2.0 , the Antarctic fishes with elevated stenothermality (T. bernacchii and Pagothenia borchgrevinki) showed larger values in the CS activity as part of the cold adaptation (Torres \& Somero 1988b).

The specific activity of the citric acid cycle enzymes [isocitrate dehydrogenase (IDH), malate dehydrogenase (MDH) and citrate synthase (CS)], the glycolytic pathway [hexokinase (HK), phosphofructokinase (PFK), piruvate kinase (PK) and $\mathrm{LDH}]$, along with other energy segments of the metabolism [piruvate dehydrogenase (PDH), creatine kinase (CK), Na,K-ATPase, glycogen phosphorylase (GPase) and cytochromo c oxidase] in fishes have been investigated as possible biomarkers for thermal (Altringham \& Johnston 1985, Brauer et al. 2005, Hardewig et al. 2004, Miller et al. 2009), osmotic stress (Morrison et al. 2006, Nakano et al. 1998, Sangiao-Alvarellos et al. 2005) and for hypoxia (Feller et al. 1991). The principal interrelations between the enzyme levels of the energy metabolism and the environmental stress agents is shown in Figure 2.

\section{Energy Metabolism}

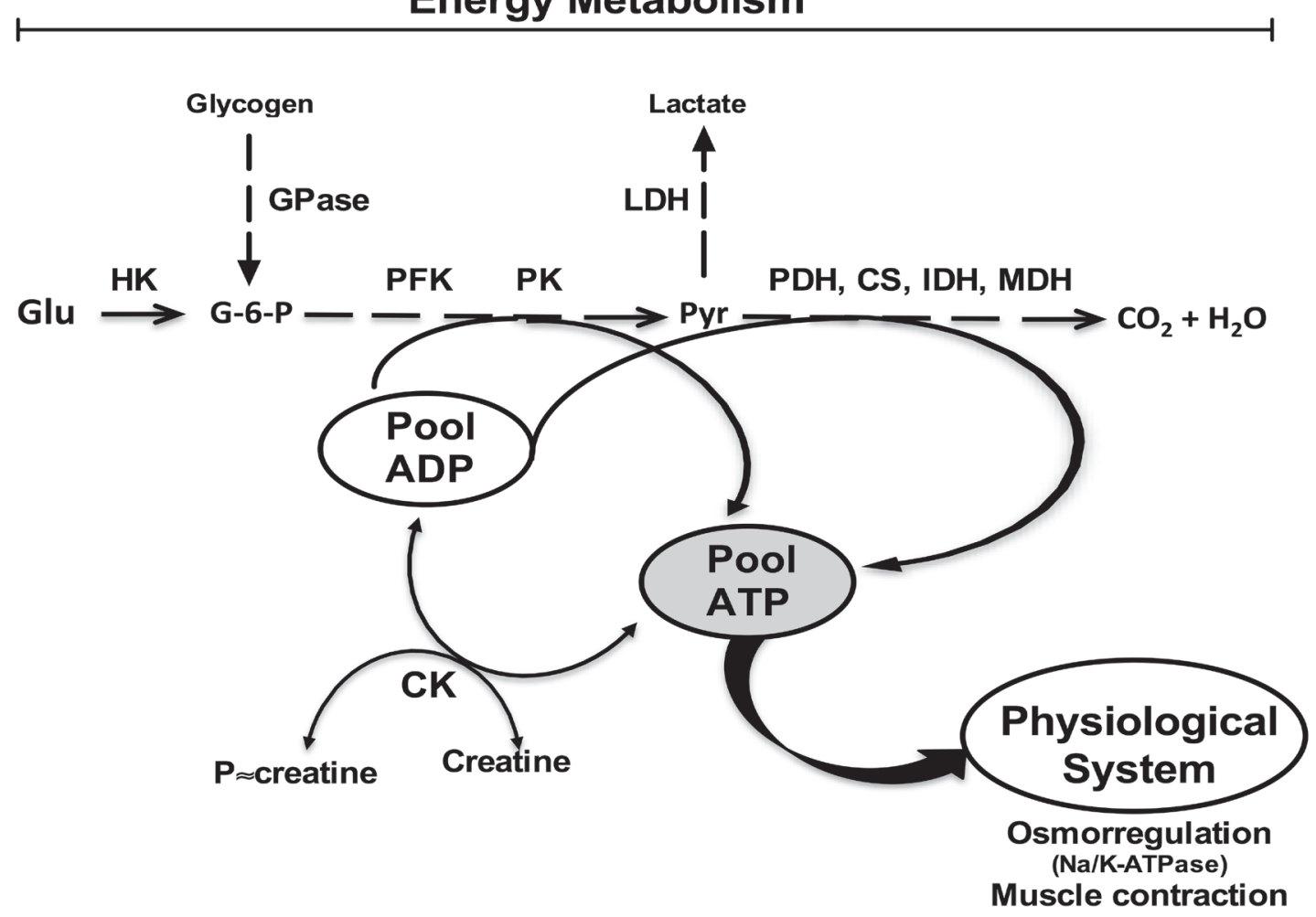

Figure 2. Interrelation between the energy metabolism, and energy demand, of the physiological systems. The glucose (Glu) oxidation in pyruvate (Pyr) and, in sequence to $\mathrm{CO}_{2}+\mathrm{H}_{2} \mathrm{O}$ is one of the main pathways of energy obtainment. The enzymes HK, PFK, PK, GPase, LDH, PDH, CS, IDH, MDH and $\mathrm{CK}$ has been used as biomarkers of the energy metabolism and $\mathrm{Na} / \mathrm{K}$-ATPase as biomarker of the energy demand to osmorregulation. 
As enzymatic specificity permits the determination of the enzymatic activity in extracts of tissues and biological fluids, in the presence of hundreds of other proteins, most used are spectrophometric methods, which is simple, rapid, specific and has low cost. However, the biological responses to the stress agents, are tissue and organism dependent, and require additional studies to identify the best biomarkers for a given change in the environment. Some enzymes are highly specific markers of environmental change. An example is $\delta$-aminolevulinic acid dehydratase (ALAD) that is inhibited by lead. However, most of the enzymatic markers respond to a wide range of stress agents in the environment (Lam 2009).

Changes in the composition of non-enzymatic components related to energy metabolism in the tissue and biological fluids have also been used as biomarkers for environmental change. After acclimatization of the Antarctic fish $P$. borchgrevinki to $4^{\circ} \mathrm{C}$ for 5-6 weeks was accompanied by a reduction in the osmolarity and an increase in the plasma glucose from $4.6 \pm 0.7 \mathrm{mmol} \mathrm{L}^{-1}$ to $5.8 \pm 1.1 \mathrm{mmol}$ $\mathrm{L}^{-1}$ (Lowe \& Davison 2005). Metabolite changes in tissues and biological fluids are often accompanied by changes in the blood hormone levels, which are also used as stress markers (Fiess et al. 2007).

Biomarker studies must also take into consideration the energy demands of the tissues. The energy demand in some tissues, increase as a function of specific physiological activities. Unlike the locomotor system, the cerebral levels of the enzymes CS and LDH, in a variety of fishes, are not affected by the energy demand for specific activities nor the nutritional state (Kawall et al. 2002). However, according to Soengas \& Adelgunde (2002), the cerebral metabolism of fishes is similar to those of other vertebrates and shows a elevated dependence on glucose as combustible energy. Depriving the alimentation alters the metabolic routine of this tissue, which then uses the ketone bodies derived from the hepatic metabolism of lipids. The enzyme levels of GPase, LDH and $\beta$-hydroxybutyrate dehydrogenase ( $\beta$-HBDH) increase, the levels of HK, PFK and glycogen synthase (GSase) are reduced. The cerebral energy metabolism of fishes is also affected by pesticides, which reduce the tissue levels of LDH, HK and GSase, and elevate the levels of glycogen phosphorylase (GPase).
On the other hand, in teleost fishes, the muscle represents a major part (more than 60\%) of the body mass. The activity of this tissue is of vital importance in the escape from the predators and prey capture (Fernández \& Calvo 2009). The aerobic energetic muscular routine in these Antarctic fishes had been associated to the presence of large quantity of lipids, high mitochondrial density, oxygen consumption and the presence of mitochondrial fat droplets (Lin et al. 1974, Kamler et al. 2001, Johnston 2003). The dominant lipids present in the notothenioids tissues are triacylglycerols composed of monounsaturated and polyunsaturated fatty acids (Hagen et al. 2000, Kamler et al. 2001). High lipid content in the tissues has been associated with the maintenance of neutral buoyance of these fish (Clarke et al. 1984) and easy oxygen diffusion into cells as well as to the subcellular compartments (Egginton \& Sidell 1989). The triacylglycerol composition of unsaturated fatty acids is strictly related with the metabolic preference in using these fatty acids as energetic fuel. The mitochondrial oxidative capacity is high for unsaturated fatty acid and the activity of the enzyme carnitine palmitoyl transferase is 2.4 times more with palmitoleoyl $\sim \mathrm{SCoA}$ than with palmitoyl SCoA (Crockett \& Sidell 1993). The enzymes fatty acyl SCoA synthetase (Grove \& Sidell 2004) and hormone-sensitive lipase (Hazel \& Sidell 2004) also has preference to unsaturated fatty acids and unsaturated triacylglycerol.

Antarctic fishes have varied diet based on proteins and lipids, coming from capture of diverse Antarctic organisms, such as euphausiids, salps, small fishes, bivalves and others (Barrera-Oro 2003). Studies with Antarctic fishes of Admiralty Bay reveled that the fatty acids composition of Notothenia coriiceps is typical of principal Antarctic benthic species (Amphipoda, Himantothallus grandifolius and Curdiea racovitzae) that serve as food to this nothothenioid (Kamler et al. 2001). The levels of vitamin $C$ and $E$ in the blood of the Antarctic fishes Pagothenia borchgrevinki and $T$. bernacchii are five to six times those found in the blood of the temperate water species (Gieseg et al. 2000), and could be related to the important physiological role of the natural antioxidants of the monounsaturated and polyunsaturated fatty acids

The gills of Antarctic fishes, in contrast to the muscles, have a low oxidative capacity for fatty acids and use a variety of circulating energetic fuels, 
especially glucose and the amino acid glutamate, to meet their energy requirements (Crockett et al. 1999). In this case, the oxidative deamination of the glutamate, catalyzed by the mitochondrial enzyme glutamate dehydrogenase, introduces its carbon chain in to the citrate cycle and provides the aminic nitrogen in the form of ammonia for excretion. Amino acids such as aspartate and alanine, could have their aminic nitrogen channelized to $\alpha$-ketoglutarate, via transamination, originating glutamate. This process permits that the nitrogen of these amino acids can be excreted in the form of ammonia through the oxidative deamination of glutamate. As urea cycle is physiologically inactive in most of the fish, the use of glutamate as ammonia acceptor in the reaction catalyzed by glutamine synthetase leads to the glutamine formation, which function as "ammonia nitrogen buffer" (Hochachka \& Somero 2002a). Before the central role of glutamate in the fish metabolism, some studies with the enzyme glutamate dehydrogenase of fish reveled its potential as biochemical biomarker in relation to the presence of pesticides and heavy metals (Mary Chandravathy \& Reddy 1994, Begum 2008).

Other key amino acid of energetic metabolism is the L-arginine. In fishes this amino acid should be present in diet and represents about $6 \%$ of the muscle amino acids (Ball et al. 2007). Of the various end products of the L-arginine metabolism, the transfer of it amid group to the amino acid glycine initiates the formation of creatine, an important "energy buffer" in fishes, marked by the reversible transfer of the high energy phosphate of ATP to creatine, catalyzed by the enzyme creatine kinase. This high energy phosphate reservoir meets the energetic requirements of the fish muscles for about 30 seconds, independent of the oxygen availability (Gibb \& Dickson 2002). Studies of the effect of fungicides ( $\mathrm{Li}$ et al.), genotoxic and cytotoxic pollutants (Napierska et al. 2009) and heavy metals (Almeida et al. 2002) on the fish metabolism indicate that the enzyme creatine kinase is a potential biomarker of environmental pollution.

On the other hand, the hydrolysis of L-arginine, catalyzed by the enzyme arginase, introduces the non protein amino acid L-ornithine in the intermediate metabolism and permits the synthesis of polyamines, proline and glutamate (Jenkinson et al. 1996). In addition to participating in the intercellular transfer of amino groups, establishing the equilibrium and composition of the cellular amino acids, along with the synthesis of glutamine in the ammonia buffer (Hochachka \& Somero 2002a), glutamate in the blood is a potential energy substrate in the gills of Antarctic fishes (Crockett et al. 1999).

\section{L-ARGININE METABOLISM}

For fishes, dietary amino acid L-arginine is essential for various metabolic activities among which growth, immunity improve, larval metamorphosis, reproduction, resistance to stress factors and infections (Li et al. 2009). The principal tissue demands of L-arginine are for protein synthesis, nitric oxide synthesis (NO), phosphocreatine and L-ornithine (Hird 1986, Wu \& Morris 1998).

The recognition of food and predators by fish, as well as their defense response and pheromonal communications are activated by detection of odors (Hashiguchi et al. 2008). The capacity of the olfactory system to discriminate odorant amino acids including L-arginine (Lipschitz \& Michel 1999) can be related with the selection of food rich in essential amino acids. With few exceptions, the requirement of fishes for L-arginine is 1.2 to $1.5 \mathrm{~g} / 100 \mathrm{~g}$ of food (Ball et al. 2007). In the young turbot (Psetta maxima) the $\mathrm{L}$-arginine during the growth phase is used principally for protein synthesis (Fournier et al. 2002, Fournier et al. 2003, Gouillou-Coustans et al. 2002). Considering that urea cycle is non-operating in these fishes, the quantity of urea excreted is related with dietary levels of L-arginine and, the hydrolysis of L-arginine has been accepted as the principal ureogenic pathway in turbot. The strong relation between the dietary levels of L-arginine and the arginase expression in the liver indicate that this is the principal enzyme responsible for ureogenic activity in turbot. Though this may not be the metabolic behavior common to all fishes, Raymond \& DeVries (1998), have registered a possible relation between the diet rich L-arginine and the ureogenic activity of Antarctic fishes.

The control of L-arginine in biological fluids has been related with the tissue argininolytic activities and arginase subcellular localization. In ureotelic animals, the hepatic arginase levels have been related to the urea cycle activity and the detoxification of ammonia (Jenkinson et al. 1996). Considering that hepatic tissues and the renal function as metabolic 
filters for the entry and exit of various compounds, respectively, the presence of elevated levels of arginase in the distal renal segment and the liver of
Antarctic fish Notothenia neglecta (Figure 3) could be related to the systemic control of L-arginine (Rodrigues et al. 2006).

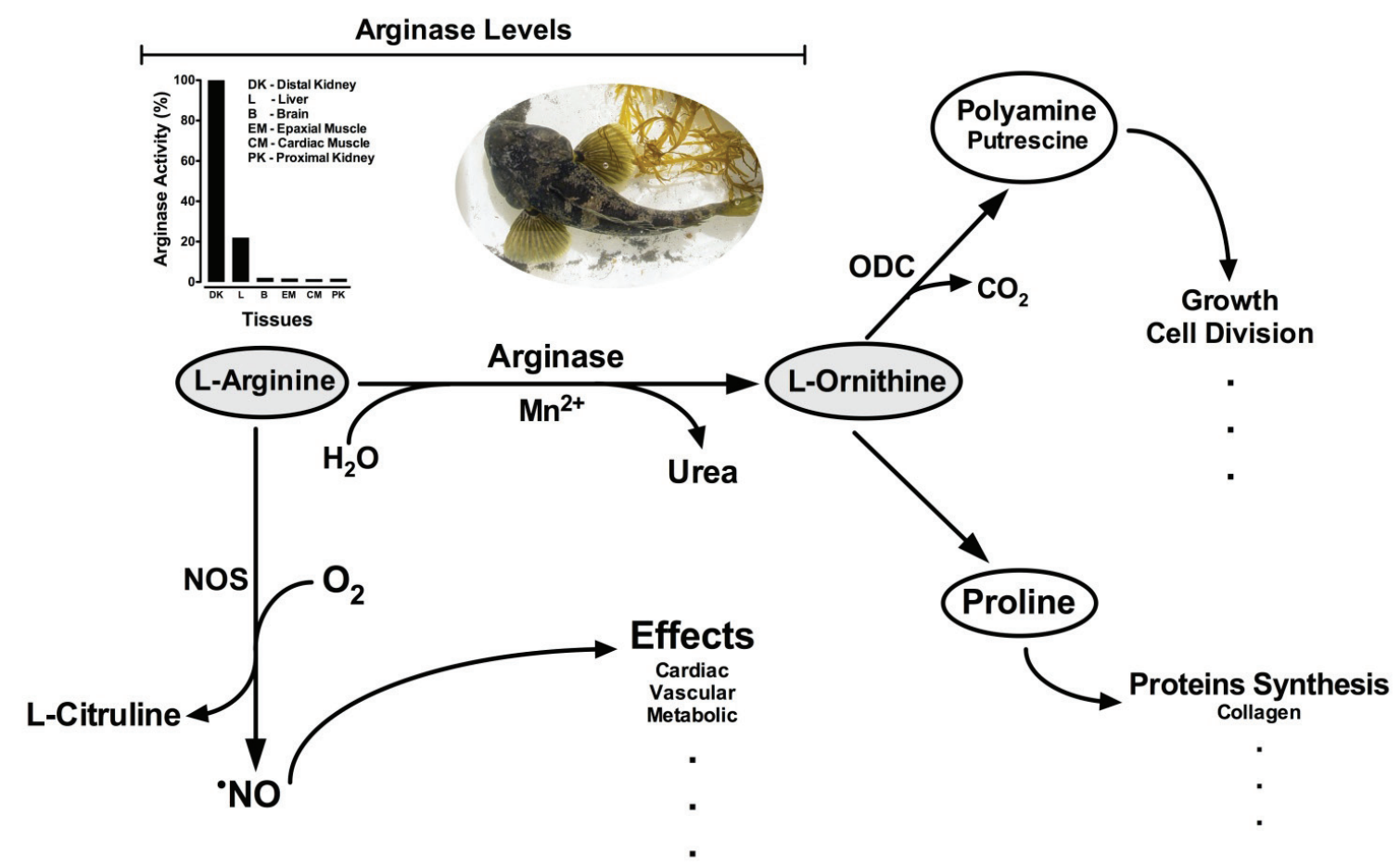

Figure 3. L-arginine metabolism. Virtually in all tissues Arginase and nitric oxide sinthetase (NOS) compete for the amino acid L-arginine. The nitric oxide $(\bullet \mathrm{NO})$ synthesized from L-arginine has many physiological effects. Non-protein amino acid L-ornithine is essential to polyamine and proline. Antarctic fish Notothenia coriiceps neglecta has high levels of the arginase in the kidney and liver, data from (Rodrigues et al. 2006).

The hydrolysis of L-arginine also provides the non-protein amino acid L-ornithine for metabolism of the polyamines and proline. The decarboxylation of ornithine to putrescine, catalyzed by the enzyme ornithine decarboxylase (ODC) which is considered as the limiting step in the synthesis of polyamines. Found in all vertebrate cells, the polyamines participate in control of cell division and modulate the genes activity involved in cell growth (Moinard et al. 2005), hence the growth and tissue regeneration in fishes has been associated with the synthesis of these compounds (Koza et al. 1992, Berge et al. 2002). The elevation of cerebral polyamine levels in goldfish Carassius auratus, during it acclimatization to $5^{\circ} \mathrm{C}$ for 2 months, indicated that these polyamines have possible protection effect in the cold adaptation of goldfish. Within the observed biochemical responses, the increase in the levels of ODC and L-ornithine during the first 10 days of acclimatization has drawn attention (Notari et al. 2004). Proline synthesis is not yet totally understood, however the synthesis of proline is capable to sustain the collagen synthesis ( $21 \%$ proline + hidroxyproline) for fish growth, considering that proline is not essential amino acid (Li et al. 2009).

After Ignarro et al. (1987) and Palmer et al. (1987) independently confirmed the chemical nature of the "endothelium-derived relaxing factor", originally described by Furchgott \& Zawadzki (1980) was the nitric oxide ( $\left.{ }^{\mathrm{NO}}\right)$, later Palmer et al. (Palmer et al. 1988) demonstrated that L-arginine is the substrate used in the $\mathrm{NO}$ synthesis. The knowledge about the synthesis and the $\mathrm{NO}$ physiological effects were amplified in the last 20 years. The L-arginine oxidation reaction forming L-citrulline and $\mathrm{NO}$ is catalyzed by enzyme nitric oxide synthases (NOS) in almost all tissues (Jobgen et al. 2006, Mori \& Gotoh 2000). Three isoforms of NOS have been identified 
and denominated as neuronal (nNOS or NOS1), inducing (iNOS or NOS2) and endothelial (eNOS or NOS3). The control of 'NO synthesis is regulated at transcriptional, post transcriptional (mRNA stabilization), post-translational (phosphorylation, glycosylation) and at level of substrates and cofactors (L-arginine) (Balligand et al. 2009). N has a wide tissue specific effect on physiological systems. In addition to its effects on the vascular endothelium and the cardiac muscle, ${ }^{\circ} \mathrm{NO}$ also affect the metabolism of carbohydrates, lipids, proteins and the interorgan metabolism of the energy substrates (Jobgen et al. 2006). As both arginase and NOS compete for the L-arginine substrate, the tissue argininolytic activity has been postulated as an important modulator of NOS activity in the endothelial inflammatory processes (Bachetti et al. 2004), as well as the myocardial contraction mediated by 'NO (Jung et al. 2006).

Nitric oxide is one of the oldest molecular signal in animal tissues for inter and intracellular communication. Even though most of the physiological and pathological studies of the NOS/ NO system were in mammals, studies in fishes reveal some particulars that make these organisms interesting biological models of the diversity of ${ }^{~} \mathrm{NO}$ action at the molecular level (Agnisola \& Pellegrino 2007). In goldfish, Wang \& Mangel (1997) showed that endogenous ${ }^{\circ} \mathrm{NO}$ modulates the horizontal cone cells in the retina and regulates the circadian rhythm. The iNOS expression in the liver macrophages and the heterophylic granulocytes in the kidneys of the rainbow trout has been interpreted as a defense mechanism of this fish (Barroso et al. 2000) and as in mammals, NOS activity modulates the cardiac function in the fish Anguilla anguilla (Imbrogno et al. 2001).

The central role of $\mathrm{NO}$ as a signal in various physiological activities is modulated by $\mathrm{NO}$ dioxygenation of hemoglobin, myoglobin and flavohemoglobins (Figure 4), which protect against the toxic effect of nitrogen (Gardner 2005). The absence of hemoglobin in the fish family Channichthyidae and of myoglobin in some species of the family is unique among vertebrates (Kock 2005, Sidell \& O'Brien 2006). Investigating the $\mathrm{NO}$ metabolism in transgenic rats without myoglobin and with the over expression of iNOS in the heart, Gödecke et al.
(2003), found that this condition leads to hypertrophy and the excess of ${ }^{\mathrm{NO}}$ to cardiac failure. However, this loss of myoglobin expression in the cardiac muscle is not an obstacle for the adaptation of some species of fish of the Channichthyidae family. The absence of respiratory pigments in the blood and tissues of icefish reduces the protection against stress from nitrosatives compounds as compared to red blooded Antarctic fish. Comparing fishes in the suborder Notothenioidei, Morlá et al. (2003) showed that the expression of eNOS and nNOS in the skeletal muscle is more in white blooded fish than in red blooded fish, reflecting a greater potential to generate ${ }^{\circ} \mathrm{NO}$.

Understanding how fishes of the Channichthydae family, transport, supply and utilize $\mathrm{O}_{2}$ as a final oxidizing agent in the respiratory processes, without the traditional respiratory pigments, has been an important question (Bacila et al. 1989, Di Prisco 2000). Compared to the red blooded Antarctic fishes, icefishes have a more dense microvasculature and capillaries with wider luminal diameter (Fitch et al. 1984, Eastman \& Lannoo 2004), elevated number and mitochondrial density (Sidell 1998, O’Brien \& Sidell 2000), and elevated cardiac debit (Sidell \& O'Brien 2006). As 'NO has a remodeling effect on the capillary network growth (Conway et al. 2001), and acts as an activation messenger in the mitochondrial biogenesis process (Nisoli et al. 2004), it should be expected that NOx (nitrate + nitrite) in the blood of icefish should be higher than those in the red-blooded Antarctic fish. However, Beers et al. (2010) found that the levels of NOx, which indicate the levels of ${ }^{\circ} \mathrm{NO}$, in the blood as well as in tissues of icefishes were much less than those found in red-blooded fishes. It is possible that NOS is being down regulated in tissues, which could be responsible for the low expression. The real $\mathrm{NO}$ tissue concentrations, that defines the physiological effects, depending on the equilibrium between the synthesis and degradation of nitric oxide, hence the absence of the respiratory pigments in the icefishes reduces the degradation of $\mathrm{NO}$ as compared to the red blooded fishes.

Hence, a number of open questions remain to be solved regarding the metabolism of ${ }^{\circ} \mathrm{NO}$ in Antarctic fishes. One of them is the control of the NOS enzyme activity by arginase. Various studies in mammals, particularly humans, indicate that the control of 
L-arginine levels by arginase is an important control point of NOS (Palm et al. 2008, Jung et al. 2010).

\section{ANTIOXIDANT DEFENSE}

Polar waters have high oxygen concentration $(0.18-0.36 \mathrm{mmol} / \mathrm{L})$ due to increased oxygen solubility at lower temperatures (Hardy \& Gunther 1935). Since the formation of reactive oxygen species (ROS) usually increases in biological systems with increased oxygen concentration, formation of free radicals could be easier in polar marine organisms (Ansaldo et al. 2000). However, little is known about antioxidant defense system in polar fishes [reviewed by Abele \& Puntarulo (2004)]. Antioxidants prevent cellular damage caused by metabolically and environmentally produced ROS such as hydrogen peroxide $\left(\mathrm{H}_{2} \mathrm{O}_{2}\right)$, superoxide anion radical $\left(\mathrm{O}_{2}^{-}\right)$and hydroxyl radical (Halliwell \& Gutteridge 1999). Antioxidant include enzymes such as superoxide dismutase (SOD), which catalyzes the dismutation of ${ }^{\prime} \mathrm{O}_{2}{ }^{-}$to water and oxygen; catalase, which reduces $\mathrm{H}_{2} \mathrm{O}_{2}$ to water and oxygen; and glutathione reductase, which regenerates reduced glutathione used as a direct scavenger of ROS or as a substrate for the antioxidant enzyme glutathione peroxidase. Vitamins $\mathrm{E}$ and $\mathrm{C}$ are non-enzymatic antioxidants (Halliwell \& Gutteridge 1999). The formation of ROS and the antioxidant defense are summarized in the Figure 4.

Comparing SOD and catalase activity in the tissue of Nototheniidae (red-blooded) and Channichthyidae (white-blooded) fishes families, Witas et al. (1984) and Cassini et al. (1993) found differences in SOD activities between these fish groups. Ansaldo et al. (2000) investigated the activity of SOD, catalase and glutathione peroxidase in the liver, gills, muscle and heart and found that, Channichthyidae fish often have low catalase activity in these tissues and high SOD activity in gills compared to Nototheniidae. The latter have high levels of SOD in blood and glutathione peroxidase in the gills compared to white-blooded fish. The erythrocytes usually contain a significant SOD fraction. However, it is important to emphasize that white-blooded fish have very few erythrocytes without hemoglobin and consequently low SOD levels in the blood. The same authors found that vitamin E content is exceptionally high in the liver of Notothenia rossii in relation to same tissue of other
Antarctic fishes investigated and it is clearly high in the heart and muscles of Cannichthyidae compared to Nototheniidae. Investigating antioxidant and cytochrome $\mathrm{c}$ oxidase enzymes in the liver of Arctic and temperate teleosts, Speers-Roesch \& Ballantyne (2005), found that cold-adapted fish have reduced antioxidant enzyme when compared to temperate species, although cytochrome c oxidase activity was higher in polar than temperate zone fish. Analyzing the data of Ansaldo et al. (2000), Fujisawa et al. (2010) concluded that great aerobic demand is not directly compensated with higher antioxidant enzyme activity. Thus, cold-adapted teleosts may have greater dependence on other antioxidant molecules such as vitamin $\mathrm{E}$ for defense against ROS damage.

Several processes such as transportation across the membrane, molecular signaling and electron transport chains of mitochondria are reliant on the physicochemical structure of cellular membranes. Ectothermic organisms regulate their membrane properties in response to temperature by altering the lipid composition of their membranes. Cold adaptation and low temperature acclimation are achieved by increasing content of low molecular weight, unsaturated and branched-chain fatty acids in their cell membranes. However, this modification renders cold-adapted ectotherms more vulnerable to oxidative damage since membrane unsaturated lipids, particularly poly-unsaturated fatty acids, are a primary target for ROS in the initiation of radicalchain lipid peroxidation (Fujisawa et al. 2010). Lipid hydroperoxides are unstable and their decomposition products, such as malondialdehyde, can damage cellular components, including DNA (Marnett 1999, Fujisawa et al. 2010). A specific constituent of vitamin E designated "marine-derived tocopherol" (MDT) occurs exclusively in marine organisms, being particularly abundant in cold-water fish, was also found in Antarctic fish (Dunlap et al. 2002). These authors investigated two Channichthyidae species and Gobionotothen gibberifrons (Nototheniidae). They found that Channichthyidae species had a lower total amount of vitamin $\mathrm{E}$ in tissues such as liver and spleen than G. gibberifrons, but a higher percentage of MDT in these and other tissues (gonads, the pectoral and myotomal muscles) than the Nototheniidae specie. Moreover, this Nototheniidae showed a high amount of $\alpha$-tocopherol in the liver (Dunlap et al. 
2002). Comparing antioxidant properties of MDT in relation to $\alpha$-tocopherol in fish oil at $0^{\circ} \mathrm{C}$ revealed that MDT has greatest reactivity to peroxyl radicals when measured at low rates of radical flux (Yamamoto et al. 2001). MDT is likely to have greater diffusion than $\alpha$-tocopherol in cold viscous lipids providing evidence that it reduces lipid peroxidation in marine ectotherms inhabiting a cold-water environment (Yamamoto et al. 2001, Dunlap et al. 2002).

Nitric oxide and superoxide anion form peroxynitrite, a strong biological oxidant and nitrating compound that triggers cytotoxic effects such as lipid peroxidation, protein nitration and oxidation, DNA oxidative damage, activation of matrix metalloproteinases, and inactivation of several enzymes (Liaudet et al. 2009). To keep appropriate - $\mathrm{NO}$ level in the cell, heme protein ${ }^{\mathrm{NO}}$ dioxygenases (NODs) catalyze the reaction of $\mathrm{O}_{2}$ and $\cdot \mathrm{NO}$ to yield the biologically benign nitrate anion $\left(\mathrm{NO}_{3}^{-}\right)$. Hemoglobin and myoglobin exhibit NOD activity and they also have antioxidant role in mammals (Schopfer et al. 2009). However, red-blooded Antarctic notothenioids have fewer erythrocytes and reduced hemoglobin concentration than temperate and tropical species. Moreover, 16 Icefish species of Channichthyidae lacked hemoglobin (Russo et al. 2010). Myoglobin is also lacking in skeletal locomotory muscle in most of notothenioid and in cardiac muscles in some species of the group (Sidell et al. 1997). In anemia induced Notothenia coriiceps (red-blooded notothenioid), significantly higher concentration of nitric oxide metabolites in their plasma was due to decrease of •NO degradation (Borley et al. 2010). In this case, $\mathrm{NO}$ mediated induction of genes related to angiogenesis to compensate lower oxygen carrying capacity in the blood of anemic fishes (Borley et al. 2010). However, excessive production of ${ }^{\mathrm{NO}}$ in the absence of NOD activity provided by hemoglobin and myoglobin could be deleterious due to potential formation of peroxynitrite. Recently, gene for neuroglobin, a monomeric heme-containing globin, which is able to bind oxygen and $\mathrm{NO}$ (Brunori et al. 2005) was found in the brain of red-blooded notothenioids and most species of icefishes (Cheng et al. 2009). Although the physiological function of neuroglobin is still unknown, ROS scavenging role in an extreme oxygen-rich environment is an attractive hypothesis.
The most studied oxidative stress biomarkers are glutathione-S-transferase (GST), catalase, SOD and glutathione peroxidase activities. Additionally, DNA strand breaks caused by the generation of toxic metabolites or excessive ROS production can be detected with the comet assay - a biomarker of genotoxicity (Nahrgang et al. 2010). Indices of oxidative stress have been investigated in fishes and include determinations of: a) lipid peroxides and end products of lipid peroxidation, such as malondialdehyde, as a marker of oxidative damage in the lipid fraction; b) protein carbonyls as indicator of oxidative damage to proteins; and c) total thiols content, because free thiols groups are considered part of cell protection against ROS and related with many redox-sensitive processes (Lushchak \& Bagnyukova 2006). The glutathione is a low molecular weight thiol, which status represents the most important indicator and determinant of the cellular redox environment (Schafer \& Buettner 2001). Nevertheless, indices of oxidative stress in Antarctic fishes have been few reported. Heise et al. (2007) determined thiobarbituric reactive substances (TBARS) as a marker of lipid peroxidation, and also protein carbonyls, reduced and oxidized glutathione, iron content (catalyst for Fenton reactions that enhances formation of hydroxyl radicals and leads lipid radical formation), lipid radicals, $\alpha$-tocopherol, antioxidant enzymes (SOD and glutathione peroxidase) and tert-butyl hydroperoxide-iniciated chemiluminescence rate (indicates imbalance between pro and antioxidant processes resulting from depletion of antioxidant compounds like glutathione, vitamin $\mathrm{E}$ and vitamin $\mathrm{C}$ in Pachycara brachycephalum. This species is a endemic Antarctic eelpout species and nonnotothenioid teleost (Brodte et al. 2006b). Heise et al. (2007) comparing P. brachycephalum acclimated at $0^{\circ} \mathrm{C}$ and $5^{\circ} \mathrm{C}$ for 11 weeks, verified that only TBARS level and glutathione peroxidase activity was increased in acclimated fishes at $5^{\circ} \mathrm{C}$ whereas other parameters were not significantly different between both groups. These authors also compared antioxidant defense between $P$. brachycephalum and Zoarces viviparous (temperate eelpout) and concluded that the Antarctic eelpout has higher antioxidant capacity, including high degree of glutathione oxidation, than the temperate eelpout. 
Nahrgang et al. (2010) investigated mRNA expressions of genes for xenobiotic metabolism and antioxidant defense in Arctic fish (Boreogadus saida) after exposure to crude oil. Expression of genes for catalase, cytosolic superoxide dismutase, phospholipid hydroperoxide glutathione peroxidase, and catalase activity was investigated. However, they were poor for oil monitoring purposes because the lack of clear pollutant concentration-dependent responses.

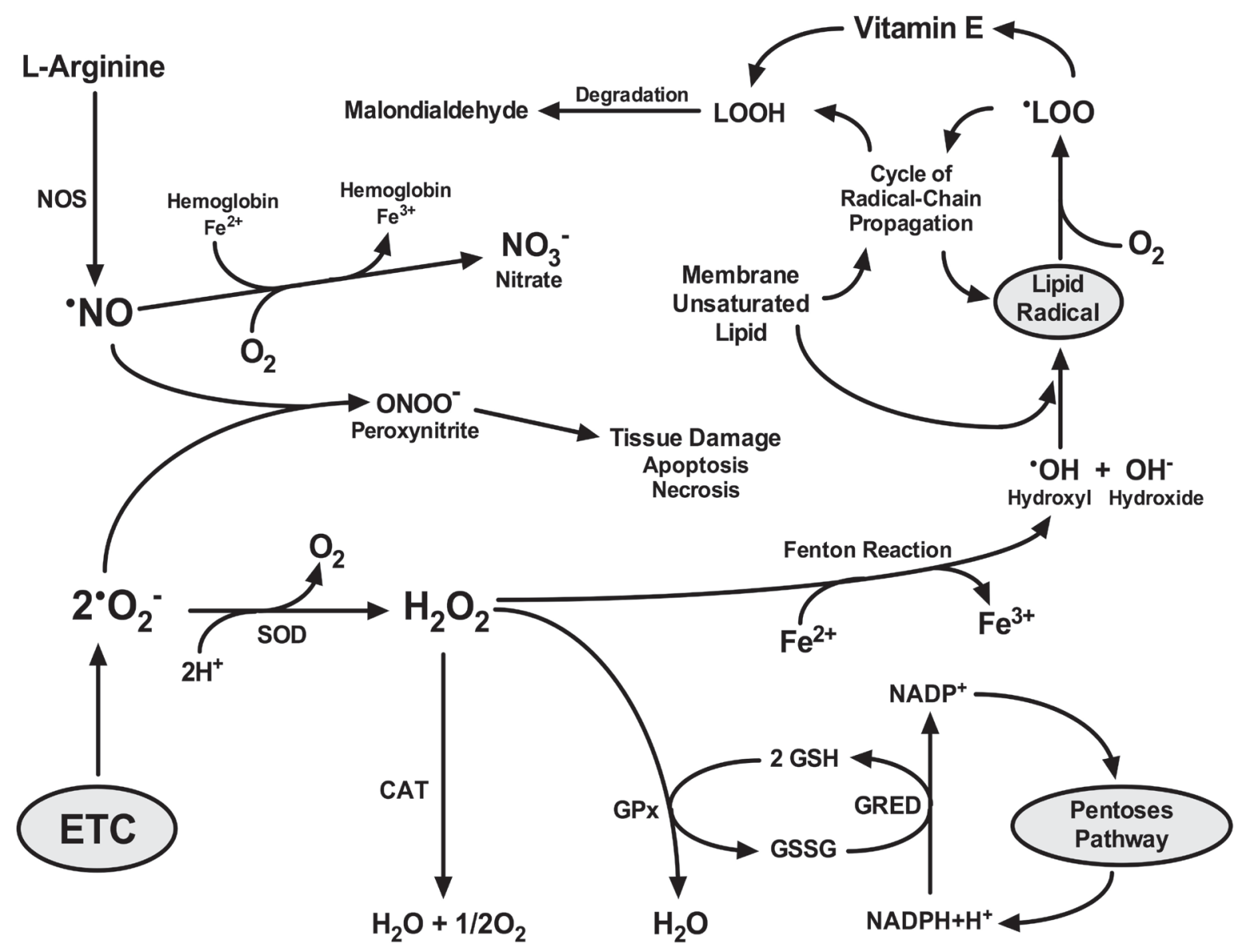

Figure 4. Formation of reactive oxygen species and antioxidant defense. CAT (catalase), GPx (glutathione peroxidase), GRED (glutathione reductase), NOS (nitric oxide synthase), SOD (superoxide dismutase), GSH (reduced glutathione), GSSG (oxidized glutathione), ${ }^{\circ} \mathrm{OH}$ (hydroxyl radical), ${ }^{\circ}{ }^{\circ}$ OO (lipid peroxyl radical), $\mathrm{LOOH}$ (lipid hydroperoxide), ${ }^{\circ} \mathrm{NO}$ (nitric oxide). Vitamin $\mathrm{E}$ is an efficient terminator of free radical propagation in membrane lipids.

Chen et al. (2008) carried out transcriptome analyses between Dissostichus mawsoni (Nototheniidae) and non-notothenioid warm-water teleost fishes to identify cold-specific expressed genes. The results revealed upregulation of several genes related to antioxidant defense, which was assembled in 3 groups: a) gene related to ROS scavenging such as for phospholipid hydroperoxide glutathione peroxidase, peroxiredoxin-5, superoxide dismutase and haptoglobin, that alleviates hemoglobin-driven oxidative stress in blood cells; b) antiapoptotic genes for Bax Inhibitor 1 (BI-1) and Translationally Controlled Tumor Protein (TCTP) with known roles in mitigating ROS-mediated apoptosis and cellular oxidative stress; c) genes involved in iron transport and storage: for ferritin and serotransferrin that bind free iron and the small peptide hormone hepcidin, that reduces iron absorption. The expression of these genes would be consistent with the need for controlling free $\mathrm{Fe}^{2+}$-catalyzed ROS generation (Chen et al. 2008). These results open a new range of targets for oxidative stress biomarkers in Antarctic fishes. 


\section{XENOBIOTICS IN ANTARCTIC ENVIRONMENT}

Organisms are constantly exposed to compounds such as synthetic drugs, poisons and antibiotics which have no metabolic function and would be harmful if accumulated in the cells. These potentially damaging compounds are often referred as xenobiotics. Some xenobiotics, such as polycyclic aromatic hydrocarbons (PAHs) and polychlorinated biphenyls (PCBs), are resistant to degradation and these compounds are listed as persistent organic pollutants (Testa \& Krämer 2006, Corsolini 2009).

PAHs are present in petroleum, coal, and are by products of fuel combustion. Some of them are carcinogenic, mutagenic and teratogenic. They are lipophilic and the larger compounds are present in the soil and sediments as they are less soluble in water, have low volatility and hence are less prone to evaporation. PAHs are the most widely spread organic pollutants (Hodgson 2004, Fetzer 2007). PCBs are synthetic organic chemicals with low water solubility, the breakdown is inversely related to the degree of chlorination where as lipophilicity is directly related. Lighter PCBs are more likely to evaporate into the atmosphere and heavy ones settle into sediments. Fish and marine mammals such as seals and whales accumulate PCBs, and may reach levels thousand times higher than in water (Hodgson 2004).

Anthropogenic influence is closely related to the presence of PAHs in the marine environment (Kennicutt II 1995, Soclo et al. 2000, Ferguson et al. 2003). Even though Antarctica remains a relatively pristine location, with ever expanding scientific activity, fisheries and growing tourism it is vulnerable to pollution. Accidents of tourist ships MS Nordkapp and MS Explorer in 2007 are clear examples (Curtosi et al. 2007). Pollution is responsible for presence of measurable amounts of PAHs and PCBs. About 90 million liters of fuel used by the scientific research activities ever year, of which $75 \%$ is diesel fuel, this leads to the release of hydrocarbons directly into the environment (Cripps 1992, Cripps \& Shears 1997).

The first report of contamination in the Antarctic ecosystems was in 1966 (George 1966, Risebrough et al. 1968). Over the last fifteen years many studies of hydrocarbon contaminants associated with research stations were conducted. Kennicutt II (1995) analyzed sediment, bivalves, limpets and fish collected from Winter Quarters Bay (WQB) at McMurdo Station, Palmer Station and remote sites of McMurdo. Widely occurring $\mathrm{PAH}$ and unusually high concentrations of PCB were observed in the sediment of WQB other than accumulation of PCBs in the organisms of this region. This demonstrates that PCBs have accumulated in the Antarctic food web at these locations. Sediment and organisms from most control and remote sites showed little or no PCBs. This indicates that long distance atmospheric transport plays a minor role in the dispersal of contaminants and the most likely source of contamination is human activity. This study also shows that intertidal zones are particularly vulnerable to exposure due to the nature of contaminant release and is most probable site of long term chronic exposure. Intertidal limpets collected at Palmer Station had higher concentrations of PCBs than subtidal limpets, this also suggests runoff source.

Weber \& Goerke (1996) analyzed various Antarctic fish species for ten non-polar xenobiotics compounds and found hexachlorobenzene (HCB) concentrations expressed on the basis of extractable organic matter did not differ from those of North Sea fish. It is possible that PCB are distributed globally by the atmospheric processes and condense in the Polar Regions. Martins et al. (2004) reported the concentrations of PAHs range from 9.45 to $270.5 \mathrm{ng}$ $\mathrm{g}^{-1}$ in surface sediments near the Brazilian station in Admiralty Bay. The highest values occurred at sites 20 meters from the out fall and lower concentrations from sites farther away than 50 meters. Martins et al. (2004) in his work showed that the aliphatic and PAHs concentrations were, in general, similar in other Antarctic areas.

Jubany station in Potter Cove in King George Island, South Shetland Islands has been operating for more than 50 years, and other than visits of large ships, is also involved in tourist activities. Potter Cove is therefore, exposed to both chronic and acute events of hydrocarbon spillages and contamination (Vodopivez et al. 2008). Curtosi et al. (2009) studied levels of 25 PAHs at Potter Cove in suspended particulate matter (SPM), surface sediment and marine organisms as fish (Notothenia coriiceps) of pelagic fauna, bivalve (Laternula elliptica) a filter feeder and intertidal limpet (Nacella concinna) a grazer of benthic community. 
In sediments, PAHs were reported to be similar to those of low level pollution sites, 14-20 $\mathrm{n} \mathrm{g} \mathrm{g}^{-1} \mathrm{dw}$ in Signy Island (Cripps 1992) and 14-280 $\mathrm{ng} \mathrm{g}^{-1} \mathrm{dw}_{\text {at }}$ Admiralty Bay (Martins et al. 2004). Whereas sites studies near shore had levels closer to 21-1572ng g-1 $\mathrm{dw}$ at Arthur Harbour (Kennicutt II et al. 1992) or 1100-2100ng g ${ }^{-1} \mathrm{dw}$ near McMurdo station (Negri et al. 2006). The total levels of PAHs in SPM were similar to sediment samples agreeing with those found in coastal soils (Curtosi et al. 2007). This data support the hypothesis that fine soil particles absorb PAHs and transported from contaminated land sites to cove by summer melt water. The PAHs concentrations (below $200 \mathrm{ng} \mathrm{g}^{-1}$ ) exhibited in $N$. corriceps tissues were low compared to the environment levels and higher levels of PAH were in the liver tissue when compared with other tissues.

Persistent organic pollutants (POPs) transport in Antarctica can be explained by global POPs models (Wania \& Mackay 1995, Wania \& Su 2004). The low temperatures and winter darkness slows down the degradation of POPs and traps them in ice. POPs are released into the environment with ice melt and enter into the trophic webs. Polar organisms do not have a well defined system to deal with foreign substances and their enzyme system for detoxification is not yet fully understood (Corsolini 2009). Hence, the accumulation of foreign substances, and their potential toxicity could be good indicators of the biological impact of pollutants.

Monitoring the contaminants (PCBs, PAHs and heavy metals) occurring naturally or from human activity is very difficult. Examining the changes in the biochemical response, particularly the impairment of the physiological processes in organisms exposed to contaminants could be used to monitor the changes in the environment. One promising approach could be to examine the impairment of the physiological processes in organisms exposed to contaminants. Biotransformation and antioxidant enzymes involved in detoxification of xenobiotics and their metabolites have been investigated as potential biomarkers.

\section{XENOBIOTICS METABOLISM}

The toxicity of the xenobiotic compounds to an organism can be affected by metabolism, where beneficial detoxification or harmful bioactivation can occur. Possible sequences of biotransformation of xenobitics are show in the Figure 5.

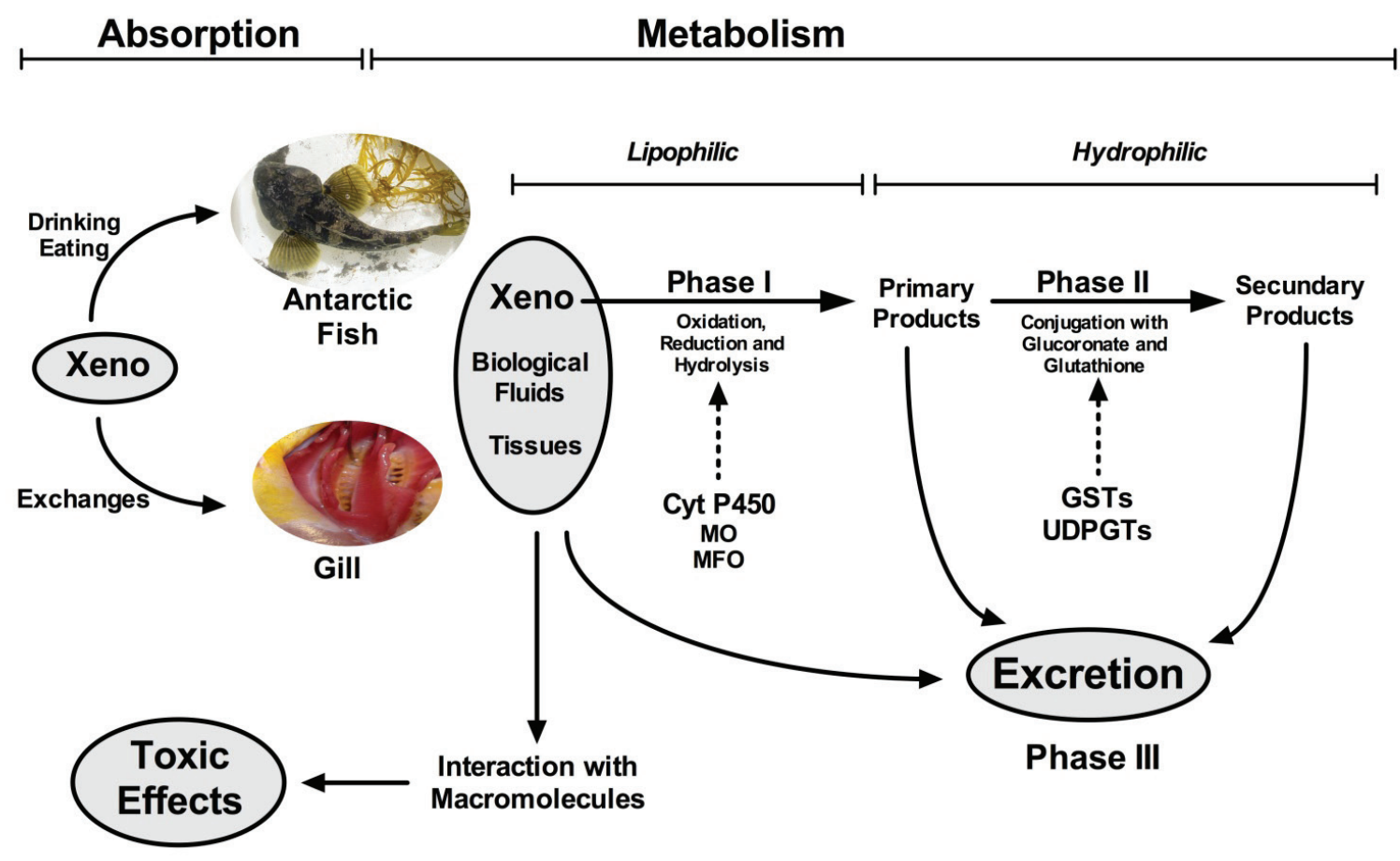

Figure 5. Metabolic pathways of xenobiotics (Xeno) in Antarctic fish. The virtually main access of xenobiotics to the tissues and biological fluids in fish is through gills and digestive tract which are the principal routes. The oxidation, reduction and hydrolyses of xenobiotics (phase I) form more soluble primary products which can be more, less or equally toxic. The conjugation with glycuronate and gluthatione (phase II) origin more hydrophilic secondary products and can be excreted preferably through bile (phase III). 
In fish, liver is most commonly involved in the detoxication of foreign compounds, which makes it as target organ. The xenobiotic metabolism is divided into three phases (Figure 5), phase I involves cytochrome P450 oxidase (CYTP450) which introduces reactive or polar compounds, phase II the modified compounds are than conjugated to polar compounds. These reactions are catalyzed by glutathione S-transferase (GTS) and UDP-glucuronyl transferase (UDPGT). The conjugated hydrophilic compounds of phase II are pumped out or may be further metabolized before being excreted in phase III (Jakoby \& Ziegler 1990, Commandeur et al. 1995, van der Oost et al. 2003).

The xenobiotic compounds in phase I are catalyzed by microsomal monooxygenase (MO) enzymes, also known as the mixed function oxidase (MFO) system, which involved mainly the cytochrome P450 (CYP450), cytochrome b5 (cyt b5) and NADPH cytochrome P450 redutase (P450 RED). CYP450 enzymes are a widely spread super family of hemeproteins; some of these enzymes are especially inducible by their substrates (Nelson et al. 1993, Bucheli \& Fent 1995). A subfamily, CYP1A is recognized as an important biomarker to exposure to PAHs, PCBs and halogentated dibenzop-dioxins (Goksøyr 1995). In most fishes CYP1A expressed is very low and are effectively induced by many planar hydrocarbons through their binding to cytosolic arylhidrocarbon receptor (AhR) and this receptor binds with nuclear translocator and acts as transcriptional activator in the promoter of CYP1A1 and other responsive gens (Handschin \& Meyer 2003). The study of T. bernacchii exposed to laboratory $\beta$-naphthoflavone ( $\beta$-NF) indicated that hepatic CYP1A showed higher sensitivity after $\beta-\mathrm{NF}$ exposure and higher methoxyresorufin O-deethylase (MEROD) activity then ethoxyresorufin O-deethylase (EROD), phase II enzymes were not affected by the exposure, indicating that their modulation is not mediated by Ah receptor (Di Bello et al. 2007).

T. bernacchii is an indicator species of CYP1A induction to assess the level of pollutants impact on local biota. Results of liver tissues from fish collected from WQB and Backdoor Bay (BDB) which is remote from human activates showed fluorescent aromatic compounds (FACs) two fold higher and 37 fold higher CYP1A expression in WQB, the CYP1A induction correlated positively with biliary FACs, even though McMurdo station cleaning program was begin in 1988 the results of present study, show that a significant contamination still exists. Since hydrocarbon breakdown is slow in Antarctic due to cold temperatures, the contamination effect remains for a considerable period of time. In fish CYP1A is catalytically expressed principally through the EROD activity (Miller et al. 1999).

Lurman et al. (2010) also evaluated the impact of environmental pollution on fish in McMurdo, using as biomarkers EROD, pentosyresorufin O-deethylase and biliary naphthalene and phenanthrene with samples of T. bernacchii and Trematomus hansoni from a control site BDB and WQB. The differences in EROD activity between polluted and control locations seem to be similar with other previous works. The WQB $T$. hansoni EROD activity was $101 \mathrm{pmol} \mathrm{min}^{-}$ ${ }^{1} \mathrm{mg}^{-1}$ and $14 \mathrm{pmol} \mathrm{min}{ }^{-1} \mathrm{mg}^{-1}$ for BDB T. hansoni. The EROD response is not proportional to the level of sediment pollution, where PAH is high. This may be due to differences in species, where T. bernacchii may be accounted for by inhibition of EROD activity by PCBs which are also high in WQB, the same was also observed with copper and cadmium also 5 to 10 fold higher in WQB. Many authors have documented inhibition of CYP1A by PCBs, and this reduction of EROD in T. bernachii, this could be a confounding factor. Lurman et al. (2010) also observed in his study that $T$. bernacchii collected form BDB and caged in WQB for 2 and 4 weeks, at 2 weeks had highest EROD activity and with 4 weeks caged the fish had greater PCB, cooper and cadmium burden, thus suppressing the EROD response. Similar results are obtained in work with T. bernacchii from Gerlache Inlet, Terra Nova Bay, Ross Sea. Induction caused by PAH was suppressed by co-exposure with $\mathrm{Cd}$ and $\mathrm{Cu}$, these results revel a complex interaction path way between different co-exposures (Benedetti et al. 2007).

Lepomis species, commonly known as sunfish, which is abundant in North America, was studied by Brammell et al. (Brammell et al. 2010) as potential biomonitoring organism for halogenated aromatic hydrocarbon and PAH, using induction of CYP1A and phase II enzymes as GST and UDPGT. Lepomis hepatic CYP1A exhibited weakly induction for PCB and highly induced for PAH indicating that sunfish could be excellent biomarker for $\mathrm{PAH}$ pollution. 
Whereas phase II enzymes remained unchanged may be indicating that these enzymes are not sensitive biomarkers for pollutants. Recently Lipophrys pholis has been pointed out as PAH pollution monitor. Exposure to PAH showed sufficient induction of EROD activity together with accumulation of FAC in the bile, suggesting use of these fish in pollution monitoring for chronic contamination as well for oil spill accidents of moderate scale. Another point to take into account determination of EROD and FACs is not expensive, rapid and easy to use (Santos et al. 2010). Three spined sticklebacks (Gasterosteus aculeatus) were exposed to humic substance (organic molecules that constitute the major part of the dissolved/natural organic matter in freshwater) of different origins and EROD activity was measured in liver and gills. EROD induction was observed primarily in gills, this would be significant to utilize EROD activity as biomarker (Andersson et al. 2010).

The available literature about xenobiotics metabolism in Antarctic fish is mainly on $T$. bernacchii. The research with other endemic fish of Antarctica would give a more accurate data about utilization of xenobiotic metabolism enzymes as biomarkers. The available data of phase I and phase II enzymes indicates that phase I has more sensitivity on pollutants effects than phase II, so phase I enzymes like EROD are preferred in using as biomarkers in Antarctic fish.

\section{HEAT SHOCK PROTEIN}

The protein activity is determined by the sequence of amino acids. The correct folding of the amino acid sequence and the compartimentation of the newly formed protein, depend on the protein assistants called chaperons. This class of proteins also prevent the aggregation of denatured protein structures and help refold them to the native state (Hochachka \& Somero 2002a). The term chaperone has its origin in the studies of the heat shock protein expression (Hsp). The expression of Hsps under thermal stress, in various organisms, help stabilize the denatured proteins, refold proteins that are denatured, and give directions those proteins that have suffered irreversible denaturation to the degradation pathways, thus avoiding cellular damage (Glickman \& Ciechanover 2002, Kalmar \& Greensmith 2009).

Comparing the gene expression of Hsps in ectotherms inhabiting thermally stable aquatic environments with those inhabiting moderately stable and highly variable thermal aquatic environments, Tormanek (2010) found that ability to induce the thermal protective response were absent or is very low in the organisms in the stable environments. Holfmann et al. (2000) investigating the induction of thermal shock responses in T. bernacchii exposed to $10^{\circ} \mathrm{C}$ for 2 hours, found that this highly stenothermic Antarctic notothenioid does not have the capacity to induce the synthesis of Hsp70. This apparent loss of function was interpreted as a consequence of the evolution to stable subzero temperatures over a period of about a million years. Working with $T$. bernacchii, Buckley et al. (2004), found that the cells when exposed to thermal shock of up to $12{ }^{\circ} \mathrm{C}$, failed to induce an increase in the mRNA hsp79 levels, the heat shock factor 1 activity (hsfl), or for that matter any other class of hsps. The inability of T. bernacchii to up-regulate the expression of various types of heat shock proteins is quite wide and is not limited to just Hsp70. For instance, the co-chaperone Hsp40 of this notothenioid is weakly induced (1.1 times) under conditions of thermal stress (Buckley \& Somero 2009).

The inability of the Antarctic notothenioid, to up-regulate the Hsp, probably occurred after the separation of the Bovichtidae family from the family of Antarctic notothenioid fishes. Through the long evolution, the thornfish Bovichtus variegatus and the non-Antarctic notothenioid, which inhabit the marine environments around New Zealand, South America and Australia, retained the capacity to synthesize them RNA of Hsp70, but only B. variegatus has a robust synthesis of the Hsp70 (Hofmann et al. 2005). The inability of the Antarctic notothenioid to induce the Hsp70 gene under thermal stress conditions, probably reside in the alteration of the gene adaptation to low temperature where it has a constantly higher levels of Hsp70. There are evidences that the adaptation to sub zero temperatures could require naturally elevated levels of chaperones to avoid the protein denaturation induced by the cold or to compensate the negative effects of low temperatures on protein folding (Place \& Hofmann 2005).

\section{CONCLUSION}

Initial studies of the metabolic enzymes of Antarctic fishes were directed to understanding the mechanisms of adaptation to the cold. However, 
human presence in the region has introduced additional new variables into these ecosystems. The levels of the energy metabolism enzymes (CS, MDH, PFK, HK, PK, IDH, CK, Na/K-ATPase, cytochrome oxidase, $\beta$-HBDH and GPase), L-arginine metabolism (arginase and NOS), antioxidant defenses (SOD, CAT, GPx and GRED) and xenobiotics (EROD e GST) have been investigated as possible biomarkers of the environmental changes mostly in tropical and temperate zone animals. Though a considerable work has been done on the utility of these enzymes as biomarkers in various organisms, there are very few studies with Antarctic organisms, especially fish. There are a number of open questions regarding the: a) the actual controls involved in the metabolism of nitric oxide involving NOS and arginase and L-arginine, $b$ ) the changes in the antioxidant metabolism in Antarctic fish arising from the enhanced production of reactive oxygen species by xenobiotics and their relation to the pollution levels, c) the actual defense mechanisms against xenobiotics, and the metabolic alterations induced by co-exposure to heavy metals whose natural concentrations are high in this region. Therefore, it is very important to have good understanding of the metabolic biomarkers to monitor the changes caused by the anthropogenic activities.

ACKNOWLEDGEMENTS: This studies was supported by INCTAPA INCT-APA (CNPq Process No. 574018/2008-5, FAPERJ E-26/170.023/2008), and supported by the Ministry of Environment, Ministry of Science and Technology, and the Secretariat for the Marine Resources Interministerial Committee (SECIRM).

\section{REFERENCES}

ABELE, D. \& PUNTARULO, S. 2004. Formation of reactive species and induction of antioxidant defence systems in polar and temperate marine invertebrates and fish. Comparative Biochemistry and Physiology - Part A: Molecular \& Integrative Physiology, 138: 405-415.

AGNISOLA, C. \& PELLEGRINO, D. 2007. Role of nitric oxide in vascular regulation in fish. Advances in Experimental Biology, 1: 293-310.

AHN, I.Y.; CHOI, H.J. \& KIM, K.W. 2003. Heavy metal pollution monitoring at King Sejong Station, King George Island, Antarctica. Ocean and Polar Research, 25: 645-652.
ALMEIDA, J.A.; DINIZ, Y.S.; MARQUES, S.F.G.; FAINE, L.A.; RIBAS, B.O.; BURNEIKO, R.C. \& NOVELLI, E.L.B. 2002. The use of the oxidative stress responses as biomarkers in Nile tilapia (Oreochromis niloticus) exposed to in vivo cadmium contamination. Environment International, 27: 673-679.

ALTRINGHAM, J.D. \& JOHNSTON, I.A. 1985. Effects of phosphate on the contractile properties of fast and slow muscle fibres from an antarctic fish. Journal of Physiology, 368: 491-500.

ANDERSSON, C.; ABRAHAMSON, A.; BRUNSTRÖM, B. \& ORBERG, J. 2010. Impact of humic substances on EROD activity in gill and liver of three-spined sticklebacks (Gasterosteus aculeatus). Chemosphere., 81: 156-160.

ANSALDO, M.; LUQUET, C.M.; EVELSON, P.A.; POLO, J.M. \& LLESUY, S. 2000. Antioxidant levels from different Antarctic fish caught around South Georgia Island and Shag Rocks. Polar Biology, 23: 160-165.

ARIGONY-NETO, J.; SIMÕES, J.C. \& BREMER, U.F. 2004. Implemantation of the Admiralty Bay Geographic Information System, King George Island, Antarctica. Pesquisa Antártica Brasileira, 4: 187-190.

BACHETTI, T.; COMINI, L.; FRANCOLINI, G.; BASTIANON, D.; VALETTI, B.; CADEI, M.; GRIGOLATO, P.; SUZUKI, H.; FINAZZI, D.; ALBERTINI, A.; CURELLO, S. \& FERRARI, R. 2004. Arginase pathway in human endothelial cells in pathophysiological conditions. Journal of Molecular and Cellular Cardiology, 37: 515-523.

BACILA, M.; ROSA, R.; RODRIGUES, E.; LUCCHIARI, P.H. \& ROSA, C.D. 1989. Tissue metabolism of the ice-fish Chaenocephalus aceratus Loenberg. Comparative Biochemistry and Physiology Part B: Biochemistry and Molecular Biology, 92: 313-318.

BALLIGAND, J.L.; FERON, O. \& DESSY, C. 2009. eNOS Activation by Physical Forces: From Short-Term Regulation of Contraction to Chronic Remodeling of Cardiovascular Tissues. Physiological Reviews, 89: 481-534.

BARRERA-ORO, E. 2003. Analysis of dietary overlap in Antarctic fish (Notothenioidei) from the South Shetland Islands: No evidence of food competition. Polar Biology, 26: 631-637.

BARROSO, J.B.; CARRERAS, A.; ESTEBAN, F.J.; PEINADO, M.A.; MARTÍNEZ-LARA, E.; VALDERRAMA, R.; JIMÉNEZ, A.; RODRIGO, J. \& LUPIÁNEZ, J.A. 2000. Molecular and 
kinetic characterization and cell type location of inducible nitric oxide synthase in fish. American Journal of Physiology - Regulatory Integrative and Comparative Physiology, 279: R650-R656.

BEERS, J.M.; BORLEY, K.A. \& SIDELL, B.D. 2010. Relationship among circulating hemoglobin, nitric oxide synthase activities and angiogenic poise in red- and whiteblooded Antarctic notothenioid fishes. Comparative Biochemistry and Physiology - A Molecular and Integrative Physiology, 156: 422-429.

BEGUM, G. 2008. Assessment of biochemical markers of carbofuran toxicity and recovery response in tissues of the freshwater teleost, Clarias Batrachus (Linn). Bulletin of Environmental Contamination and Toxicology, 81: 480-484.

BENEDETTI, M.; MARTUCCIO, G.; FATTORINI, D.; CANAPA, A.; BARUCCA, M.; NIGRO, M. \& REGOLI, F. 2007. Oxidative and modulatory effects of trace metals on metabolism of polycyclic aromatic hydrocarbons in the Antarctic fish Trematomus bernacchii. Aquatic Toxicology, 85: 167-175.

BERGE, G.E.; SVEIER, H. \& LIED, E. 2002. Effects of feeding Atlantic salmon (Salmo solar L.) imbalanced levels of lysine and arginine. Aquaculture Nutrition, 8: 239-248.

BORLEY, K.A.; BEERS, J.M. \& SIDELL, B.D. 2010. Phenylhydrazine-induced anemia causes nitric-oxide-mediated upregulation of the angiogenic pathway in Notothenia coriiceps. Journal of Experimental Biology, 213: 2865-2872.

BRAMMELL，B.F.; PRICE，D.J.; BIRGE，W.J.; HARMELLAWS, E.M.; HITRON, J.A. \& ELSKUS, A.A. 2010. Differential sensitivity of CYP1A to 3,3',4',4-tetrachlorobiphenyl and benzo(a) pyrene in two Lepomis species. Comparative Biochemistry and Physiology C Toxicology Pharmacology, 152: 42-50.

BRAUER, P.R.; SANMANN, J.N. \& PETZEL, D.H. 2005. Effects of warm acclimation on $\mathrm{Na}+, \mathrm{K}+$-ATPase $\alpha$-subunit expression in chloride cells of antarctic fish. Anatomical Record - Part A Discoveries in Molecular, Cellular, and Evolutionary Biology, 285: 600-609.

BRAUN，M.; SIMÕES， J.C.; VOGT，S.; BREMER，U.F.; BLINDOW, N.; PFENDER, M.; SAURER, H.; AQUINO, F.E. \& FERRON, F.A. 2001. An improved topographic database for King George Island: Compilation, application and outlook. Antarctic Science, 13: 41-52.

BRODTE, E.; KNUST, R. \& PÖRTNER, H. 2006a. Temperaturedependent energy allocation to growth in Antarctic and boreal eelpout (Zoarcidae). Polar Biology, 30: 95-107.
BRODTE, E.; KNUST, R.; PÖRTNER, H.O. \& ARNTZ, W.E. 2006b. Biology of the Antarctic eelpout Pachycara brachycephalum. Deep Sea Research Part II: Topical Studies in Oceanography, 53: 1131-1140.

BRUNORI, M.; GIUFFRE, A.; NIENHAUS, K.; NIENHAUS, G.U.; SCANDURRA, F.M. \& VALLONE, B. 2005. Neuroglobin, nitric oxide, and oxygen: Functional pathways and conformational changes. Proceedings of the National Academy of Sciences of the United States of America, 102: 8483-8488.

BUCHELI, T.D. \& FENT, K. 1995. Induction of cytochrome P450 as a biomarker for environmental contamination in aquatic ecosystems. Critical Reviews in Environmental Science and Technology, 25: 201-268.

BUCKLEY, B. \& SOMERO, G. 2009. cDNA microarray analysis reveals the capacity of the cold-adapted Antarctic fish Trematomus bernacchii to alter gene expression in response to heat stress. Polar Biology, 32: 403-415.

BUCKLEY, B.A.; PLACE, S.P. \& HOFMANN, G.E. 2004. Regulation of heat shock genes in isolated hepatocytes from an Antarctic fish, Trematomus bernacchii. Journal of Experimental Biology, 207: 3649-3656.

CASSINI, A.; FAVERO, M. \& ALBERGONI, V. 1993. Comparative studies of antioxidant enzymes in red-blooded and white-blooded antarctic teleost fish Pagothenia bernacchii and Chionodraco hamatus. Comparative Biochemistry and Physiology Part C: Pharmacology, Toxicology and Endocrinology, 106: 333336.

CHEN, L.; DEVRIES, A.L. \& CHENG, C.H. 1997. Evolution of antifreeze glycoprotein gene from a trypsinogen gene in Antarctic notothenioid fish. Proceedings of the National Academy of Sciences of the United States of America, 94: 3811-3816.

CHEN, Z.; CHENG, C.H.C.; ZHANG, J.; CAO, L.; CHEN, L.; ZHOU, L.; JIN, Y.; YE, H.; DENG, C.; DAI, Z.; XU, Q.; HU, P.; SUN, S. \& SHEN, Y. 2008. Transcriptomic and genomic evolution under constant cold in Antarctic notothenioid fish. Proceedings of the National Academy of Sciences of the United States of America, 105: 12944-12949.

CHENG, C.H.C.; DI PRISCO, G. \& VERDE, C. 2009. Coldadapted Antarctic fish: The discovery of neuroglobin in the dominant suborder Notothenioidei. Gene, 433: 100-101.

CLARKE, A. 2003. Costs and consequences of evolutionary temperature adaptation. Trends in Ecology and Evolution, 18: 573-581. 
CLARKE, A.; DOHERTY, N.; DEVRIES, A.L. \& EASTMAN, J.T. 1984. Lipid content and composition of three species of Antarctic fish in relation to buoyancy. Polar Biology, 3: 77-83. COMMANDEUR, J.N.; STIJNTJES, G.J. \& VERMEULEN, N.P. 1995. Enzymes and transport systems involved in the formation and disposition of glutathione S-conjugates. Role in bioactivation and detoxication mechanisms of xenobiotics. Pharmacological Reviews, 47: 271-330.

CONWAY, E.M.; COLlEN, D. \& CARMELIET, P. 2001. Molecular mechanisms of blood vessel growth. Cardiovascular Research, 49: 507-521.

COPPES PETRICORENA, Z.L. \& SOMERO, G.N. 2007. Biochemical adaptations of notothenioid fishes: Comparisons between cold temperate South American and New Zealand species and Antarctic species. Comparative Biochemistry and Physiology - A Molecular and Integrative Physiology, 147: 799807.

CORSOLINI, S. 2009. Industrial contaminants in Antarctic biota. Journal of Chromatography A, 1216: 598-612.

CRIPPS, G.C. 1992. Natural and anthropogenic hydrocarbons in the Antarctic marine environment. Marine Pollution Bulletin, 25 266-273.

CRIPPS, G.C. \& SHEARS, J. 1997. The fate in the marine environment of a minor diesel fuel spill from an Antarctic research station. Environmental Monitoring and Assessment, 46: 221-232.

CROCKETT, E.L. \& SIDELL, B.D. 1993. Substrate selectivities differ for hepatic mitochondrial and peroxisomal $\mathbb{E} \leq$-oxidation in an Antarctic fish, Notothenia gibberifrons. Biochemical Journal, 289: 427-433.

CROCKETT, E.L.; LONDRAVILLE, R.L.; WILKES, E.E. \& POPESCO, M.C. 1999. Enzymatic capacities for $\beta$-oxidation of fatty fuels are low in the gill of teleost fishes despite presence of fatty acid-binding protein. Journal of Experimental Zoology, 284: 276-285.

CURTOSI, A.; PELlETIER, E.; VODOPIVEZ, C. \& MAC CORMACK, W.P. 2007. Polycyclic aromatic hydrocarbons in soil and surface marine sediment near Jubany Station (Antarctica). Role of permafrost as a low-permeability barrier. Science of the Total Environment, 20: 193-204.

CURTOSI, A.; PELLETIER, E.; VODOPIVEZ, C.L. \& MAC CORMACK, W.P. 2009. Distribution of PAHs in the water column, sediments and biota of Potter Cove, South Shetland Islands, Antarctica. Antarctic Science, 21: 329-339.
DETRICH III, H.W. 1991. Polymerization of microtubule proteins from Antarctic fish. Pp. 248-262. In: G. Di Prisco; B. Maresca \& B. Tota (eds.). Biology of Antarctic Fish. Springer Verlag, New York, NY. 292p.

DI BELlO, D.; VACCARO, E.; LONGO, V.; REGOLI, F.; NIGRO, M.; BENEDETTI, M.; GERVASI, P.G. \& PRETTI, C. 2007. Presence and inducibility by $\beta$-naphthoflavone of CYP1A1, CYP1B1 and phase II enzymes in Trematomus bernacchii, an Antarctic fish. Aquatic Toxicology, 84: 19-26.

DI PRISCO, G. 2000. Life style and biochemical adaptation in Antarctic fishes. Journal of Marine Systems, 27: 253-265.

DRINKWATER, K.F.; BEAUGRAND, G.; KAERIYAMA, M.; KIM, S.; OTTERSEN, G.; PERRY, R.I.; PÖRTNER, H.O.; POLOVINA, J.J. \& TAKASUKA, A. 2010. On the processes linking climate to ecosystem changes. Journal of Marine Systems, 79: $374-388$.

DUNLAP, W.C.; FUJISAWA, A.; YAMAMOTO, Y.; MOYLAN, T.J. \& SIDELL, B.D. 2002. Notothenioid fish, krill and phytoplankton from Antarctica contain a vitamin E constituent ( $\alpha$-tocomonoenol) functionally associated with cold-water adaptation. Comparative Biochemistry and Physiology - B Biochemistry and Molecular Biology, 133: 299-305.

DUQUESNE, S. \& RIDDLE, M.J. 2002. Biological monitoring of heavy-metal contamination in coastal waters off Casey Station, Windmill Islands, East Antarctica. Polar Biology, 25: 206-215.

EASTMAN, J.T. 1993. Antarctic Fish Biology - Evolution in a Unique Environment. Academic Press, Inc, San Diego, CA. 322p.

EASTMAN, J.T. 2005. The nature of the diversity of Antarctic fishes. Polar Biology, 28: 93-107.

EASTMAN, J.T. \& LANNOO, M.J. 2004. Brain and sense organ anatomy and histology in hemoglobinless Antarctic icefishes (Perciformes: Notothenioidei: Channichthyidae). Journal of Morphology, 260: 117-140.

EGGINTON, S. \& SIDELL, B.D. 1989. Thermal acclimation induces adaptive changes in subcellular structure of fish skeletal muscle. American Journal of Physiology - Regulatory Integrative and Comparative Physiology, 256.

ESCHMEYER, W.N.; FRICKE, R.; FONG, J.D. \& POLACK, D.A. 2010. Marine fish diversity: history of knowledge and discovery (Pisces). Zootaxa, 2525: 19-50.

FELLER, G.; PAULY, J.P.; SMAL, A.; O'CARRA, P. \& GERDAY, C. 1991. The lactate dehydrogenase of the icefish heart: 
Biochemical adaptations to hypoxia tolerance. Biochimica et Biophysica Acta - Protein Structure and Molecular Enzymology, 1079: 343-347.

FERGUSON, S.H.; FRANZMANN, P.D.; REVILL, A.T.; SNAPE, I. \& RAYNER, J.L. 2003. The effects of nitrogen and water on mineralisation of hydrocarbons in diesel-contaminated terrestrial Antarctic soils. Cold Regions Science and Technology, 37: 197-212.

FERNÁNDEZ, D.A. \& CALVO, J. 2009.Fish muscle: The exceptional case of notothenioids. Fish Physiology and Biochemistry, 35: 43-52.

FETZER, J.C. 2007. The chemistry and analysis of large PAHs. Polycyclic Aromatic Compounds, 27: 143-162.

FIESS, J.C.; KUNKEL-PATTERSON, A.; MATHIAS, L.; RILEY, L.G.; YANCEY, P.H.; HIRANO, T. \& GRAU, E.G. 2007. Effects of environmental salinity and temperature on osmoregulatory ability, organic osmolytes, and plasma hormone profiles in the Mozambique tilapia (Oreochromis mossambicus). Comparative Biochemistry and Physiology - A Molecular and Integrative Physiology, 146: 252-264.

FITCH, N.A.; JOHNSTON, I.A. \& WOOD, R.E. 1984. Skeletal muscle capillary supply in a fish that lacks respiratory pigments. Respiration Physiology, 57: 201-211.

FOURNIER, V.; GOUILLOU-COUSTANS, M.F.; MÉTAILLER, R.; VACHOT, C.; GUEDES, M.J.; TULLI, F.; OLIVA-TELES, A.; TIBALDI, E. \& KAUSHIK, S.J. 2002. Protein and arginine requirements for maintenance and nitrogen gain in four teleosts. British Journal of Nutrition, 87: 459-469.

FOURNIER, V.; GOUILLOU-COUSTANS, M.F.; MÉTAILLER, R.; VACHOT, C.; MORICEAU, J.; LEDELLIOU, H.; HUELVAN, C.; DESBRUYERES, E. \& KAUSHIK, S.J. 2003. Excess dietary arginine affects urea excretion but does not improve $\mathrm{N}$ utilisation in rainbow trout Oncorhynchus mykiss and turbot Psetta maxima. Aquaculture, 217: 559-576.

FUJISAWA, A.; DUNLAP, W.C. \& YAMAMOTO, Y. 2010. Vitamin $\mathrm{E}$ protection in the biochemical adaptation of marine organisms to cold-water environments. Comparative Biochemistry and Physiology Part B: Biochemistry and Molecular Biology, 157: $145-158$.

FURCHGOTT, R.F. \& ZAWADZKI, J.V. 1980. The obligatory role of endothelial cells in the relaxation of arterial smooth muscle by acetylcholine. Nature, 288: 373-376.
GARDNER, P.R. 2005. Nitric oxide dioxygenase function and mechanism of flavohemoglobin, hemoglobin, myoglobin and their associated reductases. Journal of Inorganic Biochemistry, 99: 247-266.

GEORGE, D.E.H.F.J.L. 1966. Pesticides in the Antarctic. Journal of Applied Ecology, Supplement (Pesticides in the Environment and Their Effects on Wildlife): 155-167.

GIBB, A.C. \& DICKSON, K.A. 2002. Functional Morphology and Biochemical Indices of Performance: Is there a Correlation Between Metabolic Enzyme Activity and Swimming Performance? Integrative and Comparative Biology, 42: 199207.

GIESEG, S.P.; CUDDIHY, S.; HILL, J.V. \& DAVISON, W. 2000.A comparison of plasma vitamin $C$ and $E$ levels in two Antarctic and two temperate water fish species. Comparative Biochemistry and Physiology - B Biochemistry and Molecular Biology, 125: 371-378.

GLICKMAN, M.H. \& CIECHANOVER, A. 2002.The ubiquitinproteasome proteolytic pathway: Destruction for the sake of construction. Physiological Reviews, 82: 373-428.

GÖDECKE, A.; MOLOJAVYI, A.; HEGER, J.; FLÖGEL, U.; DING, Z.; JACOBY, C. \& SCHRADER, J. 2003. Myoglobin protects the heart from inducible nitric-oxide synthase (iNOS)mediated nitrosative stress. Journal of Biological Chemistry, 278: 21761-21766.

GOKSØYR, A. 1995. Use of cytochrome P450 1A (CYP1A) in fish as a biomarker of aquatic pollution. Archives of toxicology. Supplement. Archiv fur Toxikologie. Supplement, 17: 80-95.

GOUILLOU-COUSTANS, M.F.; FOURNIER, V.; MÉTAILLER, R.; VACHOT, C.; DESBRUYÈRES, E.; HUELVAN, C.; MORICEAU, J.; LE DELLIOU, H. \& KAUSHIK, S.J. 2002. Dietary arginine degradation is a major pathway in ureagenesis in juvenile turbot (Psetta maxima). Comparative Biochemistry and Physiology - A Molecular and Integrative Physiology, 132: 305-319.

GROVE, T.J. \& SIDELL, B.D. 2004. Fatty acyl CoA synthetase from Antarctic notothenioid fishes may influence substrate specificity of fat oxidation. Comparative Biochemistry and Physiology - B Biochemistry and Molecular Biology, 139: 53-63.

HAGEN, W.; KATTNER, G. \& FRIEDRICH, C. 2000. The lipid compositions of high-Antarctic notothenioid fish species with different life strategies. Polar Biology, 23: 785-791. 
HALLIWELL, B. \& GUTTERIDGE, J.M.C. 1999. Free Radicals in Biology and Medicine. Oxford University Press, New York, NY. 936p.

HANDSCHIN, C. \& MEYER, U.A. 2003. Induction of Drug Metabolism: The Role of Nuclear Receptors. Pharmacological Reviews, 55: 649-673.

HARDEWIG, I.; PÖRTNER, H.O. \& DIJK, P. 2004. How does the cold stenothermal gadoid Lota lota survive high water temperatures during summer? Journal of Comparative Physiology B: Biochemical, Systemic, and Environmental Physiology, 174: 149-156.

HARDY, A. \& GUNTHER, E. 1935. The plankton of the South Georgia whaling grounds and adjacent waters. Discovery Report 11: $1-456$

HASHIGUCHI, Y., FUTURA, Y., NISHIDA, M. 2008. Evolutionary patterns and selective pressures of odorant/ pheromone receptor gene families in teleost fishes. PLOS ONE 3(12): e4083

HASCHEMEYER, A.E. 1983. A comparative study of protein synthesis in nototheniids and icefish at Palmer Station, Antarctica. Comparative biochemistry and physiology. B, Comparative biochemistry, 76: 541-543.

HAZEL, J.R. \& SIDELL, B.D. 2004. The substrate specificity of hormone-sensitive lipase from adipose tissue of the Antarctic fish Trematomus newnesi. Journal of Experimental Biology, 207: 897-903.

HEISE, K.; ESTEVEZ, M.; PUNTARULO, S.; GALLEANO, M.; NIKINMAA, M.; PÖRTNER, H. \& ABELE, D. 2007. Effects of seasonal and latitudinal cold on oxidative stress parameters and activation of hypoxia inducible factor (HIF-1) in zoarcid fish. Journal of Comparative Physiology B: Biochemical, Systemic, and Environmental Physiology, 177: 765-777.

HIRD, F.J.R. 1986. The importance of arginine in evolution. Comparative Biochemistry and Physiology Part B: Biochemistry and Molecular Biology, 85: 285-288.

HOCHACHKA, P.W. \& SOMERO, G.N. 2002a. Biochemical adapatation: Mechanism and process in physiological evolution. Oxford University Press, New York, NY. 466p.

HOCHACHKA, P.W. \& SOMERO, G.N. 2002b. Cellular metabolism, regulation, and homeostasis. Pp. 20-100. In P. W. Hochachka \& G. N. Somero (eds.). Biochemical adaptation: Mechanism and process in physiological evolution. Oxford University Press, New York, NY. 466p.
HOCHACHKA, P.W. \& SOMERO, G.N. 2002c. Temperature. Pp. 290-449. In P. W. Hochachka \& G. N. Somero (eds). Biochemical adaptation: Mechanism and process in physiological evolution. Oxford University Press, New York, NY. 466p.

HODGSON, E. 2004. A Textbook of Modern Toxicology. Third Edition. Wiley-Interscience, New Jersey, NJ. 557p.

HOFMANN, G.E.; BUCKLEY, B.A.; AIRAKSINEN, S.; KEEN, J.E. \& SOMERO, G.N. 2000. Heat-shock protein expression is absent in the antarctic fish Trematomus bernacchii (family nototheniidae). Journal of Experimental Biology, 203: 23312339.

HOFMANN, G.E.; LUND, S.G.; PLACE, S.P. \& WHITMER, A.C. 2005. Some like it hot, some like it cold: The heat shock response is found in New Zealand but not Antarctic notothenioid fishes. Journal of Experimental Marine Biology and Ecology, 316: 79-89.

IGNARRO, L.J.; BUGA, G.M.; WOOD, K.S.; BYRNS, R.E. \& CHAUDHURI, G. 1987. Endothelium-derived relaxing factor produced and released from artery and vein is nitric oxide. Proceedings of the National Academy of Sciences of the United States of America, 84: 9265-9269.

IMBROGNO, S.; DE IURI, L.; MAZZA, R. \& TOTA, B. 2001. Nitric oxide modulates cardiac performance in the heart of Anguilla anguilla. Journal of Experimental Biology, 204: 17191727.

JAKOBY, W.B. \& ZIEGLER, D.M. 1990. The enzymes of detoxication. Journal of Biological Chemistry, 265: 2071520718

JANIOT, L.J.; SERICANO, J.L. \& MARCUCCI, O. 2003. Evidence of oil leakage from the Bahía Paraíso wreck in Arthur Harbour, Antarctica. Marine Pollution Bulletin, 46: 1619-1622.

JENKINSON, C.P.; GRODY, W.W. \& CEDERBAUM, S.D. 1996. Comparative properties of arginases. Comparative Biochemistry and Physiology Part B: Biochemistry and Molecular Biology, 114: $107-132$

JOBGEN, W.S.; FRIED, S.K.; FU, W.J.; MEININGER, C.J. \& WU, G. 2006. Regulatory role for the arginine-nitric oxide pathway in metabolism of energy substrates. The Journal of Nutritional Biochemistry, 17: 571-588.

JOHNSTON, I.A. 2003. Muscle metabolism and growth in Antarctic fishes (suborder Notothenioidei): Evolution in a cold environment. Comparative Biochemistry and Physiology - B Biochemistry and Molecular Biology, 136: 701-713. 
JUNG, A.S.; KUBO, H.; WILSON, R.; HOUSER, S.R. \& MARGULIES, K.B. 2006. Modulation of contractility by myocyte-derived arginase in normal and hypertrophied feline myocardium. American Journal of Physiology - Heart and Circulatory Physiology, 290: H1756-H1762.

JUNG, C.; GONON, A.T.; SJل $\partial Q$ QUIST, P.O.; LUNDBERG, J.O. \& PERNOW, J. 2010. Arginase inhibition mediates cardioprotection during ischaemia-reperfusion. Cardiovascular Research, 85: 147-154.

KALMAR, B. \& GREENSMITH, L. 2009. Induction of heat shock proteins for protection against oxidative stress. Advanced Drug Delivery Reviews, 61: 310-318.

KAMLER, E.; KRASICKA, B. \& RAKUSA-SUSZCZEWSKI, S. 2001. Comparison of lipid content and fatty acid composition in muscle and liver of two notothenioid fishes from Admiralty Bay (Antarctica): An eco-physiological perspective. Polar Biology, 24: 735-743.

KAWALL, H.; TORRES, J.; SIDELL, B. \& SOMERO, G. 2002. Metabolic cold adaptation in Antarctic fishes: evidence from enzymatic activities of brain. Marine Biology, 140: 279-286.

KENNICUTT II, M.C. 1995. Human contamination of the marine environment - Arthur Harbor and Mcmurdo sound, antarctica. Environmental Science and Technology, 29: 1279-1287.

KENNICUTT II, M.C.; MCDONALD, T.J.; DENOUX, G.J. \& MCDONALD, S.J. 1992. Hydrocarbon contamination on the antarctic peninsula. I. Arthur Harbor - subtidal sediments. Marine Pollution Bulletin, 24: 499-505.

KOCK, K.H. 2005. Antarctic icefishes (Channichthyidae): A unique family of fishes. A review, Part II. Polar Biology, 28: 897-909.

KOZA, R.A.; MOORE, M.J. \& STEGEMAN, J.J. 1992. Elevated ornithine decarboxylase activity in winter flounder livers exhibiting cellular lesions. Marine Environmental Research, 34: 19-23.

LAM, P.K.S. 2009. Use of biomarkers in environmental monitoring. Ocean and Coastal Management, 52: 348-354.

LI, P.; MAI, K.; TRUSHENSKI, J. \& WU, G. 2009. New developments in fish amino acid nutrition: Towards functional and environmentally oriented aquafeeds. Amino Acids, 37: 43-53.

LI, Z.H.; VELISEK, J.; GRABIC, R.; LI, P.; KOLAROVA, J. \& RANDAK, T. Use of hematological and plasma biochemical parameters to assess the chronic effects of a fungicide propiconazole on a freshwater teleost. Chemosphere. (in press).
LIAUDET, L.; VASSALLI, G. \& PACHER, P. 2009. Role of peroxynitrite in the redox regulation of cell signal transduction pathways. Frontiers in Bioscience: a Journal and Virtual Library, 14: 4809-4814.

LIN, Y.; DOBBS III, G.H. \& DEVRIES, A.L. 1974. Oxygen consumption and lipid content in red and white muscles of antarctic fishes. Journal of Experimental Zoology, 189: 379-385.

LINDE-ARIAS, A.R.; INÁCIO, A.F.; NOVO, L.A.; DE ALBURQUERQUE, C. \& MOREIRA, J.C. 2008. Multibiomarker approach in fish to assess the impact of pollution in a large Brazilian river, Paraiba do Sul. Environmental Pollution, 156: 974-979.

LIPSCHITZ, D.L. \& MICHEL, W.C. 1999. Physiological evidence for the discrL-arginine from structural analogues by the zebrafish olfactory system. Journal of Neurophysiology, 82: 3160-3167.

LOWE, C.J. \& DAVISON, W. 2005. Plasma osmolarity, glucose concentration and erythrocyte responses of two Antarctic nototheniid fishes to acute and chronic thermal change. Journal of Fish Biology, 67: 752-766.

LOWE, C.J. \& DAVISON, W. 2006. Thermal sensitivity of scope for activity in Pagothenia borchgrevinki, a cryopelagic Antarctic nototheniid fish. Polar Biology, 29: 971-977.

LURMAN, G.J.; MACDONALD, J.A. \& EVANS, C.W. 2010. Evaluating the impact of environmental pollution on fish in McMurdo Sound, Antarctica: A biomarker approach. Polar Science, 3: 246-253.

LUSHCHAK, V.I. \& BAGNYUKOVA, T.V. 2006. Temperature increase results in oxidative stress in goldfish tissues. 1. Indices of oxidative stress. Comparative Biochemistry and Physiology Part C: Toxicology \& Pharmacology, 143: 30-35.

MARK, F.; HIRSE, T. \& PÖRTNER, H. 2005. Thermal sensitivity of cellular energy budgets in some Antarctic fish hepatocytes. Polar Biology, 28: 805-814.

MARK, F.C.; LUCASSEN, M. \& PÖRTNER, H.O. 2006. Thermal sensitivity of uncoupling protein expression in polar and temperate fish. Comparative Biochemistry and Physiology - Part D: Genomics and Proteomics, 1: 365-374.

MARNETT, L.J. 1999. Lipid peroxidation - DNA damage by malondialdehyde. Mutation Research - Fundamental and Molecular Mechanisms of Mutagenesis, 424: 83-95.

MARTINS, C.C.; BÃCEGO, M.C.; TANIGUCHI, S. \& MONTONE, R.C. 2004.Aliphatic and polycyclic aromatic 
hydrocarbons in surface sediments in Admiralty Bay, King George Island, Antarctica. Antarctic Science, 16: 117-122.

MARY CHANDRAVATHY, V. \& REDDY, S.L.N. 1994.In vivo recovery of protein metabolism in gill and brain of a freshwater fish, Anabas scandens after exposure to lead nitrate. Journal of Environmental Biology, 15: 75-82.

MILLER, H.C.; MILLS, G.N.; BEMBO, D.G.; MACDONALD, J.A. \& EVANS, C.W. 1999. Induction of cytochrome P4501A (CYP1A) in Trematomus bernacchii as an indicator of environmental pollution in Antarctica: assessment by quantitative RT-PCR. Aquatic Toxicology, 44: 183-193.

MILLER, K.M.; SCHULZE, A.D.; GINTHER, N.; LI, S.; PATTERSON, D.A.; FARRELL, A.P. \& HINCH, S.G. 2009 Salmon spawning migration: Metabolic shifts and environmental triggers. Comparative Biochemistry and Physiology Part D: Genomics and Proteomics, 4: 75-89.

MOINARD, C.; CYNOBER, L. \& DE BANDT, J.-P. 2005. Polyamines: metabolism and implications in human diseases. Clinical Nutrition, 24: 184-197.

MORI, M. \& GOTOH, T. 2000. Regulation of Nitric Oxide Production by Arginine Metabolic Enzymes. Biochemical and Biophysical Research Communications, 275: 715-719.

MORLÁ, M.; AGUSTÍ, A.G.N.; RAHMAN, I.; MOTTERLINI, R.; SAUS，C.; MORALES-NIN，B.; COMPANY，J.B. \& BUSQUETS, X. 2003. Nitric oxide synthase type I (nNOS), vascular endothelial growth factor (VEGF) and myoglobinlike expression in skeletal muscle of Antarctic icefishes (Notothenioidei: Channichthyidae). Polar Biology, 26: 458-462.

MORRISON, J.F.; GUYNN, S.R.; SCOFIELD, M.A.; DOWD, F.J. \& PETZEL, D.H. 2006. Warm acclimation changes the expression of the $\mathrm{Na}+, \mathrm{K}+$-ATPase $\alpha$-subunit isoforms in Antarctic fish gills. Journal of Experimental Marine Biology and Ecology, 333: 129-139.

NAHRGANG, J.; CAMUS, L.; CARLS, M.G.; GONZALEZ, P.; JÖNSSON, M.; TABAN, I.C.; BECHMANN, R.K.; CHRISTIANSEN, J.S. \& HOP, H. 2010. Biomarker responses in polar cod (Boreogadus saida) exposed to the water soluble fraction of crude oil. Aquatic Toxicology, 97: 234-242.

NAKANO, K.; TAGAWA, M.; TAKEMURA, A. \& HIRANO, T. 1998. Temporal changes in liver carbohydrate metabolism associated with seawater transfer in Oreochromis mossambicus. Comparative Biochemistry and Physiology - B Biochemistry and Molecular Biology, 119: 721-728.
NAPIERSKA， D.; BARŠIENE， J.; MULKIEWICZ, E.; PODOLSKA, M. \& RYBAKOVAS, A. 2009. Biomarker responses in flounder Platichthys flesus from the Polish coastal area of the Baltic Sea and applications in biomonitoring. Ecotoxicology: 1-14.

NEGRI, A.; BURNS, K.; BOYLE, S.; BRINKMAN, D. \& WEBSTER, N. 2006. Contamination in sediments, bivalves and sponges of McMurdo Sound, Antarctica. Environmental Pollution, 143: 456-467.

NELSON, D.R.; KAMATAKI, T.; WAXMAN, D., J. ; GUENGERICH, F.P.; ESTABROOK, R.W.; FEYEREISEN R; GONZALEZ, F.J.; COON, M.J.; GUNSALUS, I.C.; GOTOH, O.; OKUDA, K. \& NEBERT, D.W. 1993. The P450 superfamily: update on new sequences, gene mapping, accession numbers, early trivial names of enzymes, and nomenclature. DNA Cell Biology, 12: 1-15.

NISOLI, E.; CLEMENTI, E.; MONCADA, S. \& CARRUBA, M.O. 2004.Mitochondrial biogenesis as a cellular signaling framework. Biochemical Pharmacology, 67: 1-15.

NOTARI, S.; LUCCHI, R.; TRAVERSA, U.; FABBRI, E. \& POLI, A. 2004.Reversible changes in goldfish brain polyamine concentrations and synthetic enzymes after cold exposure. Brain Research, 1006: 241-247.

O'BRIEN, K.M. \& SIDELL, B.D. 2000. The interplay among cardiac ultrastructure, metabolism and the expression of oxygenbinding proteins in Antarctic fishes. Journal of Experimental Biology, 203: 1287-1297.

PALM, F.; FRIEDERICH, M.; CARLSSON, P.O.; HANSELL, P.; TEERLINK, T. \& LISS, P. 2008. Reduced nitric oxide in diabetic kidneys due to increased hepatic arginine metabolism: Implications for renomedullary oxygen availability. American Journal of Physiology - Renal Physiology, 294: F30-F37.

PALMER, R.M.J.; ASHTON, D.S. \& MONCADA, S. 1988. Vascular endothelial cells synthesize nitric oxide from L-arginine. Nature, 333: 664-666.

PALMER, R.M.J.; FERRIGE, A.G. \& MONCADA, S. 1987. Nitric oxide release accounts for the biological activity of endothelium-derived relaxing factor. Nature, 327: 524-526.

PLACE, S.P. \& HOFMANN, G.E. 2005. Constitutive expression of a stress-inducible heat shock protein gene, hsp70, in phylogenetically distant Antarctic fish. Polar Biology, 28: 261-267. 
PÖRTNER, H.O. 2002. Climate variations and the physiological basis of temperature dependent biogeography: Systemic to molecular hierarchy of thermal tolerance in animals. Comparative Biochemistry and Physiology - A Molecular and Integrative Physiology, 132: 739-761.

RAYMOND, J.A. \& DEVRIES, A.L. 1998. Elevated concentrations and synthetic pathways of trimethylamine oxide and urea in some teleost fishes of McMurdo Sound, Antarctica. Fish Physiology and Biochemistry, 18: 387-398.

REGOLI, F.; PELlEGRINI, D.; WINSTON, G.W.; GORBI, S.; GIULIANI, S.; VIRNO-LAMBERTI, C. \& BOMPADRE, S. 2002. Application of biomarkers for assessing the biological impact of dredged materials in the Mediterranean: The relationship between antioxidant responses and susceptibility to oxidative stress in the red mullet (Mullus barbatus). Marine Pollution Bulletin, 44: 912-922.

RISEBROUGH, R.W.; RIECHE, P.; PEAKALL, D.B.; HERMAN, S.G. \& KIRVEN, M.N. 1968. Polychlorinated biphenyls in the global ecosystem. Nature, 220: 1098-1102.

RODRIGUES, E.; ROSA, R.; FUKUCHI, M.; NUMANAMI, H. \& BACILA, M. 1994. The effect of temperature on the kinetic properties of phosphaofructokinase and hexokinase from the Antarctic fish Trematomus bernacchii. Proceeding NIPR Symposium Polar Biology, 7: 110-117.

RODRIGUES, E.; RIBEIRO, A.C.M.T. \& BACILA, M. 2006. L-arginine metabolism in mitochondria isolated from the liver of Antarctic fish Notothenia rossii and Notothenia neglecta. Brazilian Archives of Biology and Technology, 49: 825-833.

RUSSO, R.; RICCIO, A.; DI PRISCO, G.; VERDE, C. \& GIORDANO, D. 2010. Molecular adaptations in Antarctic fish and bacteria. Polar Science, In Press, Corrected Proof.

SANGIAO-ALVARELLOS, S.; ARJONA, F.J.; MARTÍN DEL RÍO, M.P.; MÍGUEZ, J.M.; MANCERA, J.M. \& SOENGAS, J.L. 2005. Time course of osmoregulatory and metabolic changes during osmotic acclimation in Sparus auratus. Journal of Experimental Biology, 208: 4291-4304.

SANTOS, M.M.; SOLÉ, M.; LIMA, D.; HAMBACH, B.; FERREIRA, A.M. \& REIS-HENRIQUES, M.A. 2010. Validating a multi-biomarker approach with the shanny Lipophrys pholis to monitor oil spills in European marine ecosystems. Chemosphere, In Press.

SCHAFER, F.Q. \& BUETTNER, G.R. 2001. Redox environment of the cell as viewed through the redox state of the glutathione disulfide/glutathione couple. Free Radical Biology and Medicine, 30: 1191-1212.

SCHOPFER, M.P.; MONDAL, B.; LEE, D.-H.; SARJEANT, A.A.N. \& KARLIN, K.D. 2009. Heme/O2/•NO nitric oxide dioxygenase (NOD) reactivity: phenolic nitration via a putative heme-peroxynitrite intermediate. Journal of the American Chemical Society, 131: 11304-11305

SHAHIDUL ISLAM, M. \& TANAKA, M. 2004. Impacts of pollution on coastal and marine ecosystems including coastal and marine fisheries and approach for management: a review and synthesis. Marine Pollution Bulletin, 48: 624-649.

SIDELL, B.D. 1998. Intracellular oxygen diffusion: the roles of myoglobin and lipid at cold body temperature. The Journal of experimental biology, 201: 1119-1128.

SIDELL, B.D. \& O'BRIEN, K.M. 2006. When bad things happen to good fish: The loss of hemoglobin and myoglobin expression in Antarctic icefishes. Journal of Experimental Biology, 209: 1791-1802.

SIDELL, B.D.; VAYDA, M.E.; SMALL, D.J.; MOYLAN, T.J.; LONDRAVILLE, R.L.; YUAN, M.L.; RODNICK, K.J.; EPPLEY, Z.A. \& COSTELLO, L. 1997. Variable expression of myoglobin among the hemoglobinless Antarctic icefishes. Proceedings of the National Academy of Sciences of the United States of America, 94: 3420-3424.

SOCLO, H.H.; GARRIGUES, P. \& EWALD, M. 2000. Origin of polycyclic aromatic hydrocarbons (PAHs) in coastal marine sediments: case studies in Cotonou (Benin) and Aquitaine (France) areas. Marine Pollution Bulletin, 40: 387-396.

SOENGAS, J.L. \& ALDEGUNDE, M. 2002. Energy metabolism of fish brain. Comparative Biochemistry and Physiology - B Biochemistry and Molecular Biology, 131: 271-296.

SOMERO, G.N. 2004. Adaptation of enzymes to temperature: searching for basic "strategies". Comparative Biochemistry and Physiology Part B: Biochemistry and Molecular Biology, 139: 321-333.

SPEERS-ROESCH, B. \& BALLANTYNE, J.S. 2005. Activities of antioxidant enzymes and cytochrome c oxidase in liver of Arctic and temperate teleosts. Comparative Biochemistry and Physiology - Part A: Molecular \& Integrative Physiology, 140: 487-494.

TESTA, B. \& KRÄMER, S. 2006. The Biochemistry of Drug Metabolism - An Introduction. Chemistry \& Biodiversity, 3: 1053-1101. 
TORMANEK, L. 2010. Variation in the heat shock response and its implication for predicting the effect of global climate change on species biogeographical distribution ranges and metabolic costs. Journal of Experimental Biology, 213: 971-979.

TORRES, J.J. \& SOMERO, G.N. 1988a. Metabolism, enzymic activities and cold adaptation in Antarctic mesopelagic fishes. Marine Biology, 98: 169-180.

TORRES, J.J. \& SOMERO, G.N. 1988b. Vertical distribution and metabolism in Antarctic mesopelagic fishes. Comparative Biochemistry and Physiology Part B: Biochemistry and Molecular Biology, 90: 521-528.

VAN DER OOST, R.; BEYER, J. \& VERMEULEN, N.P.E. 2003. Fish bioaccumulation and biomarkers in environmental risk assessment: a review. Environmental Toxicology and Pharmacology, 13: 57-149.

VODOPIVEZ, C.; MAC CORMACK, W.P.; VILAAMIL, E.; CURTOSI, A.; PELLETIER, E. \& SMICHOWSKI, P. 2008. Evidence of pollution with hydrocarbons and heavy metals in the surroundings of Jubany Station. Beriche zur Polarforschung, 571: 357-364.

WANG, Y. \& MANGEL, S.C. 1997. Nitric oxide mediates circadian clock regulation of fish cone horizontal cell light responses. Investigative Ophthalmology and Visual Science, 38: S615.

WANIA, F. \& MACKAY, D. 1995. A global distribution model for persistent organic chemicals. Science of the Total Environment, 160-161: 211-232.

WANIA, F. \& SU, Y. 2004. Quantifying the Global Fractionation of Polychlorinated Biphenyls. AMBIO: A Journal of the Human Environment, 33: 161-168.

WEBER, K. \& GOERKE, H. 1996. Organochlorine compounds in fish off the Antarctic Peninsula. Chemosphere, 33: 377-392.

WHITFIELD, A.K. \& ELLIOTT, M. 2002. Fishes as indicators of environmental and ecological changes within estuaries: A review of progress and some suggestions for the future. Journal of Fish Biology, 61: 229-250.

WITAS, H.; GABRYELAK, T. \& MATKOVICS, B. 1984. Comparative studies on superoxide dismutase and catalase activities in livers of fish and other Antarctic vertebrates. Comparative Biochemistry and Physiology Part C: Comparative Pharmacology, 77: 409-411.
WU, G. \& MORRIS, S.M., JR. 1998. Arginine metabolism: nitric oxide and beyond. Biochemical Journal, 336: 1-17.

WU, R.S.S. 2002. Hypoxia: from molecular responses to ecosystem responses. Marine Pollution Bulletin, 45: 35-45.

YAMAMOTO, Y.; FUJISAWA, A.; HARA, A. \& DUNLAP, W.C. 2001. An unusual vitamin E constituent ( $\alpha$-tocomonoenol) provides enhanced antioxidant protection in marine organisms adapted to cold-water environments. Proceedings of the National Academy of Sciences of the United States of America, 98: 1314413148 .

Submetido em 15/09/2010

Aceito em 31/01/2011 